Review article

\title{
A comprehensive review on xanthone derivatives as $\alpha$-glucosidase inhibitors
}

\author{
Clementina M.M. Santos ${ }^{\text {a, b, }{ }^{*} \text {, Marisa Freitas }}{ }^{\mathrm{c}}$, Eduarda Fernandes ${ }^{\mathrm{c}, * *}$ \\ a Centro de Investigação de Montanha (CIMO), Instituto Politécnico de Bragança, Campus de Santa Apolónia, 5300-253, Bragança, Portuga \\ b Department of Chemistry, QOPNA \&University of Aveiro, Campus de Santiago, 3810-193, Aveiro, Portugal \\ ${ }^{c}$ LAQV, REQUIMTE, Laboratory of Applied Chemistry, Department of Chemical Sciences, Faculty of Pharmacy, University of Porto, 4050-313, Porto, Portugal
}

\section{A R T I C L E I N F O}

\section{Article history:}

Received 9 April 2018

Received in revised form

20 July 2018

Accepted 30 July 2018

Available online 7 August 2018

\section{Keywords:}

Diabetes

$\alpha$-Glucosidase

Inhibition

QSAR

Xanthone

\begin{abstract}
A B S T R A C T
$\alpha$-Glucosidase plays an important role in carbohydrate metabolism and is therefore an attractive therapeutic target for the treatment of diabetes, obesity and other related complications. In the last two decades, considerable interest has been given to natural and synthetic xanthone derivatives in this field of research. Herein, a comprehensive review of the literature on xanthones as inhibitors of $\alpha$-glucosidase activity, their mechanism of action, experimental procedures and structure-activity relationships have been reviewed for more than 280 analogs. With this overview we intend to motivate and challenge researchers (e.g. chemistry, biology, pharmaceutical and medicinal areas) for the design of novel xanthones as multipotent drugs and exploit the properties of this class of compounds in the management of diabetic complications.
\end{abstract}

(c) 2018 Elsevier Masson SAS. All rights reserved.

\section{Contents}

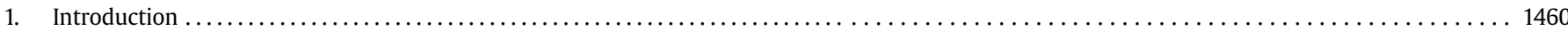

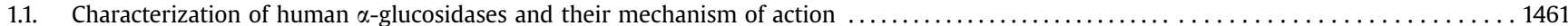

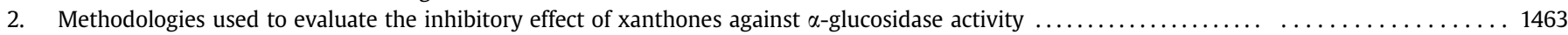

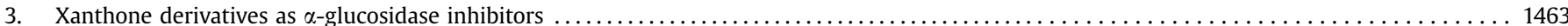

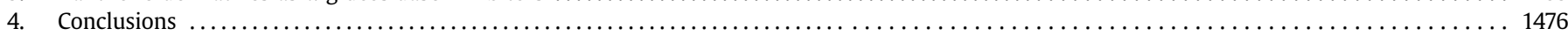

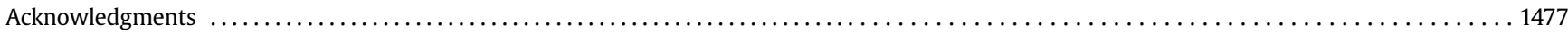

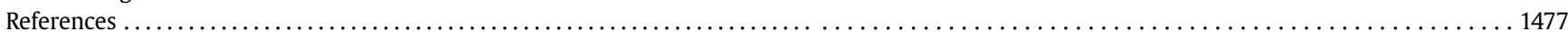

Abbreviations: Abs, absorbance; Ac, acetyl; Bn, benzyl; Bu, butyl; CoMFA, Comparative Molecular Field Analysis; CoMSIA, Comparative Molecular Similarity Indices Analysis; Et, ethyl; geranyl, $-\mathrm{CH}_{2} \mathrm{CH}=\mathrm{C}(\mathrm{Me})-\left(\mathrm{CH}_{2}\right)_{2}-\mathrm{CH}=\mathrm{C}(\mathrm{Me})_{2} ;$ glc, glucose; $\mathrm{IC}_{50}$, inhibitory effect at $50 \%$; isoprenyl, $-\mathrm{CH}_{2}-\mathrm{CH}=\mathrm{C}(\mathrm{Me})_{2} ; \mathrm{Me}$, methyl; MLR, multiple linear regression; NA, no activity was found; NT, not tested; PNP, $p$ nitrophenol; PNPG, $p$-nitrophenol glucoside; QSAR, quantitative structure-activity relationship; rha, rhamnose; ref, reference; TBS, tert-butyltrimethylsilyl; xyl, xylose.

* Corresponding author. Centro de Investigação de Montanha (CIMO), Instituto Politécnico de Bragança, Campus de Santa Apolónia, 5300, Bragança, Portugal.

** Corresponding author. LAQV, REQUIMTE, Laboratory of Applied Chemistry, Department of Chemical Sciences, Faculty of Pharmacy, University of Porto, Rua de Jorge Viterbo Ferreira n. ${ }^{\circ} 228,4050$, Porto, Portugal.

E-mail addresses: clems@ipb.pt (C.M.M. Santos), egracas@ff.up.pt (E. Fernandes).

\section{Introduction}

9H-Xanthen-9-ones, or simply xanthones, are oxygencontaining heterocyclic compounds known as secondary metabolites of some families of higher plants (especially those of the Guttiferae, Gentianacea, Moraceae, Clusiaceae and Polygalaceae families), and in a few families of fungi, lichens and bacteria [1-3]. Parent xanthone itself $\mathbf{1}$ (Fig. 1) has not been found as a natural product. However, in 2002, Oldenburg et al. described the occurrence of this compound in crude oils extracted from offshore Norway, possibly formed by oxidation of xanthenes in the reservoir or originated by geosynthesis from aromatic precursors [4]. The chemical profile of xanthone nucleus can be highly variable (from 



Fig. 1. Chemical structure and numbering system of the xanthone skeleton.

$\mathrm{R}^{1}$ to $\mathrm{R}^{8}$, Fig. 1), containing hydroxyl, methoxyl, prenyl or glycosyl as simple substituents or appearing as complex units, such as dimers, polycyclic or xanthonolignoid structures [1,3,5]. In order to compare the description of the compounds along this manuscript, the positions of the substituents from 1 to 8 will be maintained in the xanthone nucleus for all molecules, even in the absence of substituents in some positions of the main skeleton. For more complex structures, the numbering of the substituents will proceed chronologically.

Along the years, several reviews have been focused on the biological properties of xanthone derivatives, namely in the antimicrobial [6-8], anticancer [6-9], anti-inflammatory [6-8], antimalarial $[6,8,10]$ and antioxidant activities $[6-8,11]$. Recently, the anti-diabetic activity of xanthones has also been discussed, but the data remains sparse and/or inconveniently discussed $[6,8,11]$.

Diabetes is a chronic metabolic disorder caused by abnormal carbohydrate metabolism with a consequent hyperglycemia status, occurring from deficiencies in insulin secretion, action, or both. Insulin is a pancreatic hormone responsible for regulating blood glucose levels as part of energy metabolism. Whenever there is hyperglycemia, the brain recognizes it and sends a message through nerve impulses to pancreas and other organs in order to decrease their activity. Maintenance of glucose homeostasis is achieved by the hormonal regulation of glucose uptake and endogenous glucose production, primarily in the liver, muscle and adipose tissue. An alteration in normal glucose homeostasis may occur by a combination of one or more factors that include eight pathophysiological mechanisms: (i) reduced insulin secretion from pancreatic $\beta$-cells, (ii) elevated glucagon secretion from pancreatic $\alpha$-cells, (iii) increased production of glucose in liver, (iv) neurotransmitter dysfunction and insulin resistance in the brain, (v) enhanced lipolysis, (vi) increased renal glucose reabsorption, (vii) reduced incretin effect in the small intestine, and (vii) impaired or diminished glucose uptake in peripheral tissues such as skeletal muscle, adipose tissues and liver, resulting in hyperglycemic condition [12]. This postprandial hyperglycemia can cause severe damage, dysfunction and failure of multiple organs and tissues, with progressive metabolic complications such as neuropathy, retinopathy, nephropathy and cardiovascular diseases [15].

There are three main types of diabetes. Type 1 diabetes, also known as insulin-dependent, is a chronic, autoimmune process that occurs when the immune system attacks the insulinproducing pancreatic $\beta$-cells, inducing a loss of ability to produce insulin or a decrease in its production. Type 2 diabetes occurs when the body cannot properly use insulin, decreasing the ability to regulate glucose metabolism, in a mechanism called insulin resistance. With the evolution of the disease, pancreas can also decrease the insulin production - insulin deficiency - leading to hyperglycemia and other related complications. Gestational diabetes, which occurs during the pregnancy, develops when pregnancy hormones block the action of insulin and represent a great risk of morbidity and mortality to mother, fetus and subsequent neonate. Type 2 diabetes is the most common form of diabetes, comprising $80 \%-$ $90 \%$ of all the cases [13-16].

Diabetes is certainly one of the major public health problems, approaching epidemic proportions globally. The remission or cure of diabetes is not yet straightforward, and, until now, there are no effective treatment to modulate this disease. In that sense, several pharmacological approaches have been used to control diabetes. The first line of action include intensive lifestyle modifications combined with oral medication for the treatment of obesity, glycemic control, stimulation of insulin secretion and insulin sensitizers, or the administration of injectable modified insulins [17]. The classes of oral medications currently approved for the treatment of hyperglycemia in type 2 diabetes include a series of biguanides, sulfonylureas, meglitinide, thiazolidinedione (TZD), $\alpha$ glucosidase inhibitors, dipeptidyl peptidase 4 (DPP-4) inhibitors and sodium-glucose cotransporter (SGLT2) inhibitors [12,18]. Despite the variety of the available drugs, the response and efficacy of the therapy is overly-dependent on the patients [12], inciting several research groups all around the world in the pursuit of novel and broad-spectrum antidiabetic agents. To fulfill this goal, over the years, a great number of heterocyclic compounds, from natural or synthetic origin have been studied, some of them with promising inhibitory effects against one of the main targets of diabetes treatment, the enzyme $\alpha$-glucosidase [19-23]. In this perspective and due to our undergoing interest in the chemistry of xanthones [24-26], in this comprehensive review, we will provide a systematic survey about the inhibitory profile of a series of natural and synthetic xanthone derivatives against $\alpha$-glucosidase, establishing, whenever possible, structure-activity relationships. Besides that, it is also our propose to organize and provide useful information about the natural occurrence and isolation of the natural compounds and the currently used methodologies for the evaluation of $\alpha$-glucosidase inhibitory activity.

\subsection{Characterization of human $\alpha$-glucosidases and their mechanism of action}

Starch is the main energy source in human diet. This polysaccharide is synthesized in green plants and it is a mixture of two polymers: amylose $(\approx 25 \%)$ and amylopectin $(\approx 75 \%)$, in different amounts and with different characteristics, depending on the botanic origin. Amylose is a linear chain polymer of $\alpha$-D-glucopyranosyl residues, linked by $\alpha-1,4$ glycosidic bonds, while amylopectin is a branched glucan of $\alpha$-D-glucopyranosyl unites linked by $\alpha-1,4$ glycosidic bonds, but with occasional $\alpha$-1,6-glycosidic bonds, which are responsible for the branching [27,28].

The digestion process of starchy foods to free glucose is called dietary gluconeogenesis and involves six enzymes, including two $\alpha$ amylases (salivary and pancreatic) and four mucosal $\alpha$-glucosidases [ $N$-terminal subunits of maltase-glucoamylase (NtMGAM) and sucrase-isomaltase (NtSI), in the in the domain closest to the membrane anchor; and C-terminal (CtMGAM and CtSI) in the luminal domain], anchored to the brush-border epithelial cells of the small intestine (Fig. 2) [29,30].

The starch digesting enzymes $\alpha$-amylase, SI and MGAM belong to the class of enzymes known as glycoside hydrolases (GH). This class of enzymes cleave the glycosidic bond between two carbohydrate molecules, commonly found in natural polymers, $10^{17}$ times faster than the uncatalyzed reaction, making GHs some of the most proficient enzymes. Salivary and pancreatic $\alpha$-amylases belong to the GH13 family whereas SI and MGAM belong to the GH31 family.

Initially, salivary and pancreatic $\alpha$-amylases (EC 3.2.1.1) hydrolyze internal $\alpha-1,4$ glycosidic bonds of amylose, but bypasses the oligosaccharides such as maltose (two glucose molecules) and maltriose (three glucose molecules), while from the hydrolysis of amylopectin, results a range of branched oligosaccharides (which are a mixture of branched glucans and small linear glucans), due to the non-cleavage of $\alpha-1,6$ bonds or their adjacent $\alpha-1,4$ glycosidic 
Amylose


NtMGAM: $N$-terminal maltase-glucoamylase CtMGAM: C-terminal maltase-glucoamylase NtSI: $N$-terminal sucrase-isomaltase CtSI: C-terminal sucrase-isomaltase

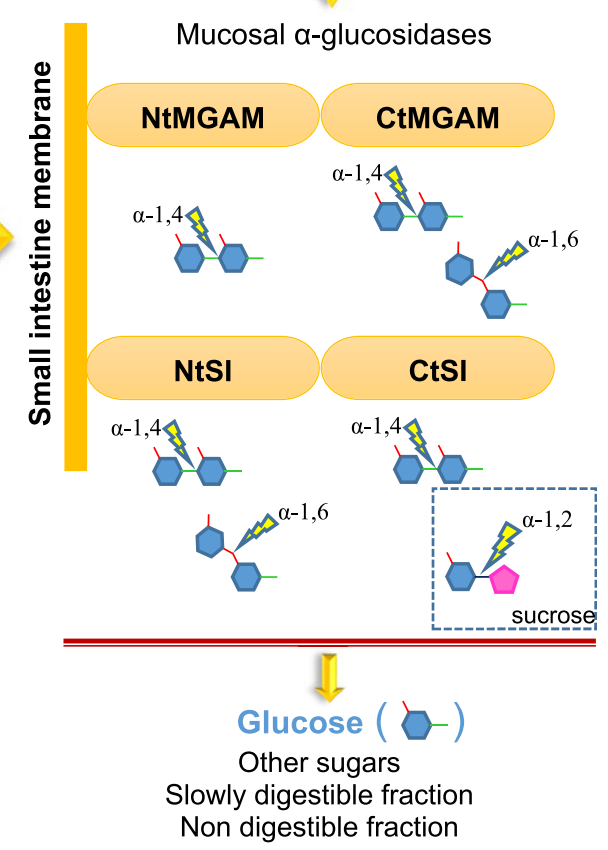

Fig. 2. Schematic diagram of the human digestion process by the digestive enzymes.

bonds. The resultant glucans can be eventually hydrolyzed to glucose in the lumen by the action of both MGAM (EC 3.2.1.20 and 3.2.1.3) and SI (EC 3.2.148 and 3.2.10).

MGAM comprises about $2 \%$ of brush-border membrane proteins, being less abundant than SI [31]. However, CtMGAM is the subunit with the highest activity among the above mentioned enzymes [32]. Additionally, in contrast to SI that only exist in intestine, MGAM is also found in kidney, being absent in colon [31]. Unlike SI, whose domains are proteolytically cleaved and can be isolated and assayed separately, MGAM exists as a single polypeptide chain.

SI is expressed in the intestinal brush border and it is responsible for almost all sucrase activity and about $60-80 \%$ of maltase activity [33]. This enzyme is mostly localized in the small intestine, although low levels of SI can be found in the colon in early development [34]. SI is a type II membrane glycoprotein which is $N$ glycosylated in endoplasmic reticulum and then transported to the Golgi apparatus, where it is $\mathrm{N}$ - and $\mathrm{O}$-glycosylated [33]. After glycosylation, the enzyme is transported and inserted into the apical membrane of enterocytes as a single, large polypeptide chain and processed by extracellular pancreatic proteases to generate free CtSI and membrane-bound NtSI subunits [35].

Both enzymes (MGAM and SI) can cleave the main $\alpha-1,4$ glycosidic linkage of glucans, while the CtMGAM and NtSI have additional minor activities on $\alpha-1,6$ glycosidic branch linkage (Fig. 2). It is important to refer that NtMGAM and NtSI have maximum activity against maltose, while CtMGAM and CtSI prefer glucans up to four glucose residues, through a mechanism that retains the configuration at the anomeric center. In addition, sucrase active site can split sucrose into glucose and fructose [36,37]. Lin et al. reported that mucosal $\alpha$-glucosidases may also digest starch (granules and gelatinized molecules) directly to free glucose and act with $\alpha$-amylases at the initial stage of the digestion process [36]. The similarity in the amino acid sequence of SI and MGAM complexes and of their catalytic subunits are around $59 \%$ and $40-60 \%$, respectively, and it has been proposed that the shared domain structures arose from duplication and divergence of an ancestral gene, which itself had already undergone tandem gene duplication [27].

Taking into account this knowledge, the inhibition of both $\alpha$ amylase and $\alpha$-glucosidase shall delay glucose absorption into the blood, suppressing postprandial hyperglycemia, being these enzymes excellent targets for the treatment of type 2 diabetes.

Currently, four $\alpha$-glucosidase inhibitors are therapeutically used: acarbose, miglitol, voglibose and emiglitate. Among these, acarbose, the first $\alpha$-glucosidase inhibitor, introduced into the market in the 1990s, is by far the most prescribed drug. Acarbose, miglitol and voglibose have been the most studied inhibitors, and among them, acarbose originated the best outcomes [38]. However, it is well documented that the use of these inhibitors are associated with serious side-effects such as flatulence, abdominal pain, and diarrhea. These unwanted effects has encouraged researchers 
towards the discovery of newer and safer second generation of agents [39]. Being aware that none of the commercially available $\alpha$ glucosidase inhibitors are xanthone-type compounds, the increased number of publications using xanthones in the selected therapeutic target for the management of diabetes complications led us to infer about the importance of this scaffold in this medicinal area.

\section{Methodologies used to evaluate the inhibitory effect of xanthones against $\alpha$-glucosidase activity}

The most common assays to evaluate the in vitro inhibitory effect of xanthones against $\alpha$-glucosidase activity are based on colorimetric enzyme-inhibitor screenings. Currently, the most used method determined spectrophotometrically $(400-405 \mathrm{~nm})$ the activity of a yeast culture of Saccharomyces cerevisiae, using as substrate the $p$-nitrophenyl glucopyranoside (PNPG) and the inhibitors prepared in DMSO or in mixtures with water or phosphate buffer (Table 1). The simplest protocols involve a direct incubation of the three reactants (enzyme, inhibitor and substrate) at $37^{\circ} \mathrm{C}$ during $15-30 \mathrm{~min}$ and the absorbance is monitored during that period of time [40-44]. Nevertheless, a pre-incubation period of the enzyme and the inhibitors, before the addition of the substrate is also frequently performed, during $5 \mathrm{~min}$ [45], $10 \mathrm{~min}$ [46,47], $15 \mathrm{~min}$ [48-54] and $30 \mathrm{~min}$ [55-61]. In these cases, incubations prior the addition of substrate occur also at $37^{\circ} \mathrm{C}$ in periods of 5-60 min. Nguyen and coworkers proposed an alternative protocol with a pre-incubation at $28{ }^{\circ} \mathrm{C}$ for a period of $10 \mathrm{~min}$, followed by the addition of the substrate to start the reaction and an incubation of the reactional mixture for an additional 30-35 min [62,63]. Another important detail is the use, in some cases, of a basic solution (sodium carbonate $0.1-1 \mathrm{M}$ or sodium hydroxide $2 \mathrm{M}$ ) in variable amounts, to stop the reaction, which is especially important for end point absorbance reads. In all the cases, $\alpha$-glucosidase activity was determined by measuring the yellow-colored $p$ nitrophenol (PNP) released from PNPG at 400-405 nm, using a microplate photometer.

A single example of using rat intestinal $\alpha$-glucosidase was reported by Phoboo et al. [64]. Briefly, a pre-incubation of the inhibitors under study with the enzyme in phosphate buffer, occurs at $25^{\circ} \mathrm{C}$ during $10 \mathrm{~min}$. After that, PNPG was added and the reaction mixture was incubated for more $5 \mathrm{~min}$. Before and after incubation, absorbance readings were recorded at $405 \mathrm{~nm}$ using a microplate reader (Table 1 ).

Ichiki et al. published in 2007 an $\alpha$-glucosidase inhibitory assay using a commercially available enzyme isolated from rice. The protocol is quite different to those previously described, starting with a pre-incubation of the enzyme $(1.4 \mu \mathrm{g} / \mathrm{mL})$ with the tested inhibitors in 2-morpholinoethanesulfonic acid (MES) buffer pH 6.3, at $25^{\circ} \mathrm{C}$, for $15 \mathrm{~min}$. Then, the reaction was initiated by addition of $2 \mathrm{mM}$ PNPG followed by incubation at $70{ }^{\circ} \mathrm{C}$ for $90 \mathrm{~min}$ and stopped by the addition of $1 \mathrm{M}$ sodium carbonate. The release of PNP was measured spectrophotometrically at $405 \mathrm{~nm}$ (Table 1) [65].

The unique report studying the inhibitory effects of a xanthone on $\alpha$-glucosidase activity, having sucrose as substrate, was published by Li et al. in 2004 [66]. This protocol includes a preincubation of the enzyme with the samples, in DMSO, for a period of $5 \mathrm{~min}$. Then, $37 \mathrm{mM}$ of sucrose was added and incubated at $37^{\circ} \mathrm{C}$, for $30 \mathrm{~min}$. The reaction was stopped by heating the reaction mixture at $90-100^{\circ} \mathrm{C}$ for $10 \mathrm{~min}$. The formation of glucose was determined using a kit (purchased commercially) for glucose determination [66]. In another study, Ryu et al. also monitorized $\alpha$ glucosidase inhibitory activity using maltose as substrate. In this protocol, the yeast enzyme was incubated in phosphate buffer with maltose and tested inhibitors for $30 \mathrm{~min}$. The absorbance was measured at $540 \mathrm{~nm}$ during the 30 min of incubation [44].

The $\alpha$-glucosidase inhibitory activity was expressed as $\%$ inhibition and calculated as follows (Eq. (1)):

$\%$ Inhibition $=\frac{A b s_{\text {control }}-A b s_{\text {sample }}}{A b s_{\text {control }}} \times 100$,

where the control represents the assay in which the sample is replaced by the solvent used in its preparation.

In some cases, the $\mathrm{IC}_{50}$ value, defined as the concentration of the sample that inhibits $50 \%$ the $\alpha$-glucosidase activity, was calculated from the dose-inhibition curves.

The use of fluorimetric assays for the determination of $\alpha$ glucosidase activity inhibition by xanthones was reported only in a couple of papers. Bosman et al. started this protocol by the preparation of an enzyme mixture in phosphate buffer, after an ultrasonic treatment of rat intestinal acetone powder $\alpha$-glucosidase [67]. The enzyme mixture was diluted to a concentration that provide a fluorescence $(\mathrm{FL})$ of 50,000 arbitrary units $\left(\lambda_{\mathrm{ex}} 360 \mathrm{~nm}\right.$; $\lambda_{\mathrm{em}}$ $460 \mathrm{~nm}$ ) on release of methylumbelliferone from the substrate, 7O- $\alpha$-D-glucopyranosyl-4-methylumbelliferone, after $20 \mathrm{~min}$. A pre-incubation of the enzyme with the tested inhibitors, at $37^{\circ} \mathrm{C}$, was performed during $15 \mathrm{~min}$. Then, the fluorescence was monitored over $30 \mathrm{~min}$ after the addition of $1.2 \mathrm{mM}$ of the substrate. The net fluorescence (Net FL) was calculated as the difference between the fluorescence at $30 \mathrm{~min}$ and the fluorescence at $0 \mathrm{~min}$. The enzyme activity (\%) was calculated by the following equation (Eq. (2)) [67]:

$\%$ Enzyme activity $=\frac{\text { Net } \mathrm{FL}_{\text {sample }}}{\text { Net } F L_{\text {control }}} \times 100$,

Another fluorimetric assay was published by Ryu et al. where the $\alpha$-glucosidase activity in B16F10 melanoma cells was accessed. B16F10 cell lysates were incubated with the inhibitors under study and the substrate 7-O- $\alpha$-D-glucopyranosyl-4-methylumbelliferone, in sodium acetate buffer at $37^{\circ} \mathrm{C}$, during $48 \mathrm{~h}$. The reaction was stopped by the addition of $0.4 \mathrm{M}$ of glycine buffer and the fluorescence read immediately ( $\lambda_{\mathrm{ex}} 363 \mathrm{~nm} ; \lambda_{\mathrm{em}} 444 \mathrm{~nm}$ ) [68].

Unfortunately, the nature of the enzyme, the concentrations of enzyme and substrate, the times of pre-incubations varies among the authors being difficult to reproduce the assay and even to analyze and/or compare the published data [69-74]. In that sense, we tried our best to systematize the available information about the experimental conditions used in the assays of the inhibitory effect of xanthones against $\alpha$-glucosidase activity (Table 1 ).

\section{Xanthone derivatives as $\alpha$-glucosidase inhibitors}

To the best of our knowledge, reports on xanthones as inhibitors of $\alpha$-glucosidase activity have appeared only in the beginning of the 21 st century. Since then, several studies addressing the inhibitory properties of a variety of analogs have appeared, highlighting the pharmacological importance of this class of compounds. Thus, we will provide a comprehensive survey on the $\alpha$-glucosidase inhibitory activity by a series of pure xanthones isolated from natural sources (excluding the effects of the extracts themselves), as well as, by a range of synthetic analogs prepared for this propose, comprising more than 280 derivatives.

Mangiferin 2, a C-glucosyl xanthone (2-C- $\beta$-D-glucopyranosyl1,3,6,7-tetrahydroxy-9H-xanthen-9-one), is the most abundant natural glycosylated xanthone and widely reported in the literature for their biological activities [75-77]. Several groups dedicate their research to study the inhibitory activity of mangiferin (both from natural or synthetic origin) against $\alpha$-glucosidases from different 
Table 1

Spectrophotometric methodologies used to evaluate the in vitro inhibitory effect of xanthones against $\alpha$-glucosidase activity.

\begin{tabular}{|c|c|c|c|c|c|c|c|c|c|c|c|c|c|c|c|}
\hline \multirow[t]{2}{*}{ Source } & \multicolumn{2}{|l|}{ Enzyme } & \multicolumn{3}{|l|}{ Samples } & \multicolumn{2}{|c|}{ Pre-incubation ${ }^{*}$} & \multicolumn{2}{|l|}{ PNGP } & \multicolumn{2}{|l|}{ Incubation } & \multirow{2}{*}{ Stop reaction } & \multicolumn{2}{|c|}{ Absorbance } & \multirow[t]{2}{*}{ Ref. } \\
\hline & Amount $(\mu \mathrm{L})$ & Conc. & Solvent & Amount $(\mu \mathrm{L})$ & Range & Temp. $\left({ }^{\circ} \mathrm{C}\right)$ & ) Time (min) & Amount $(\mu \mathrm{L})$ & ) Conc. (mM) & ) Temp. $\left({ }^{\circ} \mathrm{C}\right)$ & Time (min) & & $\lambda(\mathrm{nm})$ & ) Read & \\
\hline yeast & - & $250 \mathrm{U} / \mathrm{mL}$ & - & - & - & - & - & - & 500 & 37 & - & - & 400 & Kinetics & [40] \\
\hline yeast & 20 & $0.1 \mathrm{U} / \mathrm{mL}$ & DMSO & 10 & - & - & - & 40 & 1 & 37 & 15 & - & 405 & Kinetics & [41] \\
\hline yeast & 25 & $0.2 \mathrm{U} / \mathrm{mL}$ & DMSO & 625 & $1-250(\mu \mathrm{M})$ & - & - & 25 & 3 & 37 & 30 & $\mathrm{Na}_{2} \mathrm{CO}_{3} 0.1 \mathrm{M}$ & 401 & End point & [42] \\
\hline yeast & - & - & - & - & - & - & - & - & - & 37 & 30 & - & 405 & End point & [43] \\
\hline yeast & 50 & $0.01 \mathrm{U} / \mathrm{mL}$ & DMSO & 10 & - & - & - & 50 & 1 & - & 30 & $\mathrm{NaOH} 2 \mathrm{M}$ & 405 & End point & [44] \\
\hline yeast & 30 & $2 \mathrm{U} / \mathrm{mL}$ & - & 20 & - & 37 & 5 & - & 3 & 37 & 30 & $\mathrm{Na}_{2} \mathrm{CO}_{3} 1 \mathrm{M}$ & 405 & End point & [45] \\
\hline yeast & 50 & $20 \mathrm{U} / \mathrm{mL}$ & phosphate buffer & 100 & $10-100(\mu \mathrm{M})$ & 37 & 10 & 100 & 20 & 37 & 30 & $\mathrm{Na}_{2} \mathrm{CO}_{3} 0.2 \mathrm{M}$ & 405 & End point & [46] \\
\hline yeast & 100 & $0.35 \mathrm{U} / \mathrm{mL}$ & DMSO & 50 & - & 37 & 10 & 100 & 2.5 & 37 & 20 & $\mathrm{Na}_{2} \mathrm{CO}_{3} 1 \mathrm{M}$ & 405 & End point & [47] \\
\hline yeast & 20 & $0.6 \mathrm{U} / \mathrm{mL}$ & $\mathrm{H}_{2} \mathrm{O} / 0.5 \%$ DMSO & 120 & - & 37 & 15 & 20 & 5 & 37 & - & $\mathrm{Na}_{2} \mathrm{CO}_{3} 0.2 \mathrm{M}$ & 1405 & End point & {$[48]$} \\
\hline yeast & 30 & - & phosphate buffer & 80 & - & 37 & 15 & 30 & 3 & 37 & 5 & - & 405 & End point & [49] \\
\hline yeast & 20 & $0.2 \mathrm{U} / \mathrm{mL}$ & phosphate buffer & 10 & - & 37 & 15 & 20 & 2.5 & 37 & 15 & $\mathrm{Na}_{2} \mathrm{CO}_{3}$ & 405 & End point & [50] \\
\hline yeast & 20 & $0.2 \mathrm{U} / \mathrm{mL}$ & phosphate buffer $/ 5 \%$ DMSO & 8 & - & 37 & 15 & 20 & 2.5 & 37 & 15 & $\mathrm{Na}_{2} \mathrm{CO}_{3} 0.2 \mathrm{M}$ & 405 & End point & [51] \\
\hline yeast & 20 & $0.4 \mathrm{U} / \mathrm{mL}$ & $\mathrm{H}_{2} \mathrm{O} / 0.5 \%$ DMSO & 120 & - & 37 & 15 & 20 & 5 & 37 & 30 & $\mathrm{Na}_{2} \mathrm{CO}_{3} 0.2 \mathrm{M}$ & 405 & End point & [52] \\
\hline yeast & 30 & $0.2 \mathrm{U} / \mathrm{mL}$ & phosphate buffer $/ 5 \%$ DMSO & 120 & - & 37 & 15 & 20 & 5 & 37 & 30 & $\mathrm{Na}_{2} \mathrm{CO}_{3} 1 \mathrm{M}$ & 405 & End point & [53] \\
\hline yeast & 20 & $0.2 \mathrm{U} / \mathrm{mL}$ & - & - & - & 37 & 15 & 20 & 0.7 & 37 & 30 & - & 400 & End point & [54] \\
\hline yeast & 20 & $0.4 \mathrm{U} / \mathrm{mL}$ & DMSO & 20 & - & 37 & 30 & 10 & 3 & 37 & 60 & $\mathrm{Na}_{2} \mathrm{CO}_{3} 0.1 \mathrm{M}$ & 1405 & End point & [55] \\
\hline yeast & - & - & - & - & - & 37 & 30 & - & - & 37 & 60 & - & 400 & End point & [56-61] \\
\hline yeast & - & $0.05 \mathrm{U} / \mathrm{mL}$ & phosphate buffer $/ 5 \%$ DMSO & - & - & 28 & 10 & - & 1 & 28 & 30 & - & 405 & End point & [62] \\
\hline yeast & 80 & $0.05 \mathrm{U} / \mathrm{mL}$ & DMSO & 10 & - & 28 & 10 & 20 & 1 & 28 & 35 & - & 405 & End point & [63] \\
\hline rat intestine & 100 & $1 \mathrm{U} / \mathrm{mL}$ & $\mathrm{H}_{2} \mathrm{O} /$ DMSO & 50 & - & 25 & 10 & 50 & 5 & 25 & 5 & - & 405 & $\begin{array}{l}\text { Before and after } \\
\text { incubation }\end{array}$ & {$[64]$} \\
\hline rice & - & $1.4 \mu \mathrm{g} / \mathrm{mL}$ & MES buffer & & $0.003-3 \mathrm{mg} / \mathrm{mL}$ & 25 & 15 & - & 2 & 70 & 90 & $\mathrm{Na}_{2} \mathrm{CO}_{3} 1 \mathrm{M}$ & 405 & End point & [65] \\
\hline - & - & $0.2 \mathrm{U} / \mathrm{mL}$ & phosphate buffer & - & - & - & - & - & 0.7 & 37 & - & - & 400 & Kinetic & [70] \\
\hline - & 10 & $20 \mathrm{U} / \mathrm{mL}$ & DMSO & 2200 & - & - & - & 10 & 3 & 37 & 30 & $\mathrm{Na}_{2} \mathrm{CO}_{3} 0.1 \mathrm{M}$ & 405 & End point & [74] \\
\hline - & 20 & $0.8 \mathrm{U} / \mathrm{mL}$ & phosphate buffer & 120 & - & 37 & 15 & 20 & 5 & 37 & 15 & $\mathrm{Na}_{2} \mathrm{CO}_{3} 0.2 \mathrm{M}$ & 1405 & End point & [69] \\
\hline _- & 20 & $0.2 \mathrm{U} / \mathrm{mL}$ & phosphate buffer & 10 & $3.1-62.5(\mu \mathrm{M})$ & 37 & 15 & 20 & 4.5 & 37 & - & - & 400 & Kinetic & {$[71,72]$} \\
\hline _- & 20 & $0.2 \mathrm{U} / \mathrm{mL}$ & DMSO & 20 & - & 37 & 15 & 20 & 2 & - & - & $\mathrm{Na}_{2} \mathrm{CO}_{3} 0.2 \mathrm{M}$ & 405 & End point & [73] \\
\hline
\end{tabular}

"In pre-incubation period, enzyme and inhibitors are incubated together, before substrate is added.

- No indication about the parameter is given in the reference. 
Table 2

Inhibitory effect of mangiferin $\mathbf{2}$ on $\alpha$-glucosidases activity.

\begin{tabular}{|c|c|c|c|c|}
\hline Compound source & Enzyme source & Inhibitory effect & Positive control & Ref. \\
\hline Roots of Salacia reticulata & $\begin{array}{l}\text { sucrase (from rat) } \\
\text { isomaltase (from rat) } \\
\text { maltase (from rat) }\end{array}$ & $\begin{array}{l}\mathrm{IC}_{50}=87 \mu \mathrm{g} / \mathrm{mL} \\
\mathrm{IC}_{50}=216 \mu \mathrm{g} / \mathrm{mL} \\
42 \%{ }^{300 \mu \mathrm{g} / \mathrm{mLa}}\end{array}$ & $\begin{array}{l}\text { (data not shown) } \\
\text { (data not shown) } \\
\text { (data not shown) }\end{array}$ & [78] \\
\hline Roots of Salacia oblonga & $\alpha$-glucosidase (yeast-derived) & $\mathrm{IC}_{50}=22.7 \mu \mathrm{g} / \mathrm{mL}$ & acarbose $\left(\mathrm{IC}_{50}=53.9 \mu \mathrm{g} / \mathrm{mL}\right)$ & {$[39,66]$} \\
\hline Rhizoma of Anemarrhena asphodeloides ${ }^{\mathrm{b}}$ & $\alpha$-glucosidase (from rice) & $\mathrm{IC}_{50}=96.1 \mu \mathrm{g} / \mathrm{mL}$ & acarbose $\left(\mathrm{IC}_{50}=2.39 \mu \mathrm{g} / \mathrm{mL}\right)$ & {$[64]$} \\
\hline Leaves of Aquilaria sinensis & $\begin{array}{l}\alpha \text {-glucosidase (no source } \\
\text { indication) }\end{array}$ & $\begin{array}{l}\mathrm{IC}_{50}=126.5 \pm 17.8 \mu \mathrm{g} / \mathrm{mL} \\
(299.7 \mu \mathrm{M})\end{array}$ & $\begin{array}{l}\text { acarbose }\left(\mathrm{IC}_{50}=372.0 \pm 37.8 \mu \mathrm{g} / \mathrm{mL}\right) \\
(576.2 \mu \mathrm{M})\end{array}$ & [69] \\
\hline $\begin{array}{l}\text { Whole plant of Iris loczyi and rhizomes of Iris } \\
\text { unguicularis }\end{array}$ & $\begin{array}{l}\alpha \text {-glucosidase (no source } \\
\text { indication) }\end{array}$ & $\mathrm{IC}_{50}=0.478 \pm 0.001 \mathrm{mM}$ & acarbose $\left(\mathrm{IC}_{50}=1.52 \pm 0.004 \mathrm{mM}\right)$ & {$[70,79]$} \\
\hline Whole plant of Swertia kouitchensis & $\begin{array}{l}\alpha \text {-glucosidase (from } \\
\text { Saccharomyces) }\end{array}$ & $\mathrm{IC}_{50}=296 \pm 52 \mu \mathrm{M}$ & acarbose $\left(\mathrm{IC}_{50}=627 \pm 28 \mu \mathrm{M}\right)$ & {$[48]$} \\
\hline Whole plant of Swertia mussotii & $\begin{array}{l}\alpha \text {-glucosidase (maltase) } \\
\alpha \text {-glucosidase (maltase) }\end{array}$ & $\begin{array}{l}\mathrm{IC}_{50}=13 \pm 0.2 \mu \mathrm{M} \\
\mathrm{IC}_{50}=13.3 \pm 0.1 \mu \mathrm{M}\end{array}$ & $\begin{array}{l}\text { acarbose }\left(\mathrm{IC}_{50}=39.6 \pm 0.1 \mu \mathrm{M}\right) \\
\text { acarbose }\left(\mathrm{IC}_{50}=39.8 \pm 0.1 \mu \mathrm{M}\right)\end{array}$ & $\begin{array}{l}{[71]} \\
{[72]}\end{array}$ \\
\hline Leaves and stems of Cyclopia genistoides ${ }^{\mathrm{C}}$ & $\begin{array}{l}\alpha \text {-glucosidase (mammalian } \\
\text { source) }\end{array}$ & $53 \% 100 \mu \mathrm{M}$ & acarbose $\left(50 \%{ }^{65 \mu \mathrm{M}}\right)$ & {$[67]$} \\
\hline From synthesis & $\begin{array}{l}\alpha \text {-glucosidase (from } \\
\text { Saccharomyces) }\end{array}$ & NA & 1-deoxynojirimycin $\left(79.6 \%{ }^{100 \mu \mathrm{M}}\right)$ & {$[80]$} \\
\hline From synthesis & $\begin{array}{l}\beta \text {-glucosidase (from almonds) } \\
\alpha \text {-glucosidase (from rat } \\
\text { intestine) }\end{array}$ & $\begin{array}{l}\mathrm{NA} \\
\mathrm{IC}_{50}=52171.37 \mu \mathrm{M}\end{array}$ & $\begin{array}{l}\text { 1-deoxynojirimycin }\left(81.2 \%{ }^{100 \mu \mathrm{M}}\right) \\
\text { acarbose }\left(\mathrm{IC}_{50}=1824.23 \mu \mathrm{M}\right)\end{array}$ & [64] \\
\hline From synthesis $^{\mathrm{d}}$ & $\begin{array}{l}\alpha \text {-glucosidase (no source } \\
\text { indication) }\end{array}$ & $\mathrm{IC}_{50}=85.35 \pm 6.39 \mu \mathrm{g} / \mathrm{mL}$ & acarbose $\left(\mathrm{IC}_{50}=900 \mu \mathrm{g} / \mathrm{mL}\right)$ & {$[73]$} \\
\hline
\end{tabular}<smiles>O=c1c2cc(O)c(O)cc2oc2cc(O)c([C@]3(O)O[C@H](CO)[C@@H](O)[C@H](O)[C@H]3O)c(O)c12</smiles><smiles>O=c1c2cc(O)c(O)cc2oc2c([C@H]3O[C@H](CO)[C@@H](O)[C@H](O)[C@H]3O)c(O)cc(O)c12</smiles>

Fig. 3. Chemical structure of mangiferin 7-O- $\beta$-D-glucopyranoside $\mathbf{3}$ and isomangiferin 4.

sources, being the results listed in Table 2 .

The inhibitory effects of mangiferin $\mathbf{2}$ against $\alpha$-glucosidase has been reported since 2001 [78] (Table 2). This xanthone has been isolated in variable amounts and using different extraction techniques from different parts of plants, belonging to families as Celastraceae (Salacia species), Asparagaceae (Anemarrhena species), Thymelaeaceae (Aquilaria species), Iridaceae (Iris species), Gentianaceae (Swertia species), Fabaceae (Cyclopia species), most of them traditionally used for the prevention and treatment of diabetes and obesity. It is not an easy task to make a comparison of results, since the source of the enzyme differ among the studies (yeast $[39,48,66]$, rice [64] or mammalian origin [67,78]), and in some cases, the source of the enzyme is omitted [69-72] or the effect of a positive control is not presented [78]. Nevertheless, in general, the effect of natural mangiferin $\mathbf{2}$ is higher than the positive control, acarbose. Exceptions are the effects of mangiferin 2 and mangiferin 7-O- $\beta$-D-glucopyranoside $\mathbf{3}$ isolated from rhizoma of Anemarrhena asphodeloides, on the inhibition of $\alpha$-glucosidase from rice, showing $\mathrm{IC}_{50}$ values of $96.1 \mu \mathrm{g} / \mathrm{mL}$ and $158 \mu \mathrm{g} / \mathrm{mL}$, respectively, higher than the $\mathrm{IC}_{50}$ of acarbose $\left(\mathrm{IC}_{50}=2.39 \mu \mathrm{g} / \mathrm{mL}\right)$ [64]. Interestingly, studies using mangiferin 2 from a synthetic origin, showed no activity in the inhibition of $\alpha$-glucosidase activity, obtained from yeast [80] and rat intestine [64] or against $\beta$ glucosidase isolated from almonds (Table 2) [80]. However, Nian et al. found lower $\mathrm{IC}_{50}$ values for mangiferin $\mathbf{2}$ and isomangiferin $\mathbf{4}$ (Fig. 3) $(85.35 \pm 6.39 \mu \mathrm{g} / \mathrm{mL}$ and $76.98 \pm 5.18 \mu \mathrm{g} / \mathrm{mL}$, respectively) than the positive control acarbose ( $\mathrm{IC}_{50}=900 \mu \mathrm{g} / \mathrm{mL}$ ) against an $\alpha$ glucosidase from an unknown source (Table 2) [73].

A series of other xanthones have been isolated from the Gentianaceae family, mainly from plants of the genus Swertia (S. kouitchensis [48], S. corymbosa [74], S. mussotii Franch [71,72,81] and S. bimaculata [52]). Three main types of substituents can be found in their structures, being hydroxyl, methoxyl and glycosyl the most frequent ones, alone or in combination. Most of the isolated compounds 5-64 exhibited moderate to strong $\alpha$-glucosidase inhibitory properties, as depicted in Table 3 . The effect of the positive control, when reported, is listed in the end of each specie presented in Table 3. Li et al. published in 2017, a review, which elegantly summarized the chemical constituents and pharmacological activities of Swertia plants, which includes some data on xanthones and their $\alpha$-glucosidase inhibition [82].

As shown in Table 3, among the compounds isolated from S. kouitchensis 5-24, xanthones 6, 8-10, 15 and 16 were the most active ones, with $\mathrm{IC}_{50}$ values of $383 \pm 18,360 \pm 39,371 \pm 22$, $184 \pm 23,126 \pm 23$ and $451 \pm 41 \mu \mathrm{M}$, respectively (acarbose, $\left.\mathrm{IC}_{50}=627 \pm 28 \mu \mathrm{M}\right)$. The presence of a hydroxyl group located at C1 or C-8 (compounds $\mathbf{1 0}$ and $\mathbf{1 5}$ ) seems to be important for the high inhibitory activity against $\alpha$-glucosidase, while the steric hindrance produced by the diglycoside residue at position C-7 (compounds 13, 20, 22 and 23) lowered the inhibitory activity [48]. Meanwhile, a series of five hydroxylated xanthones were isolated from S. corymbosa, 25-29, and none of them presented a better inhibitory activity ( $\mathrm{IC}_{50}$ ranging from $23.2 \pm 1.5$ to $44.5 \pm 1.1 \mu \mathrm{M}$ ) when compared with the positive control, acarbose $\left(\mathrm{IC}_{50}=15.2 \pm 0.6 \mu \mathrm{M}\right)$ 
Table 3

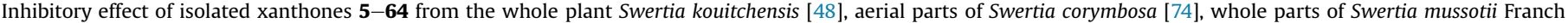
[71,72], overground parts of Swertia mussotii Franch [81] and whole parts of Swertia bimaculata [52] on $\alpha$-glucosidase activity.

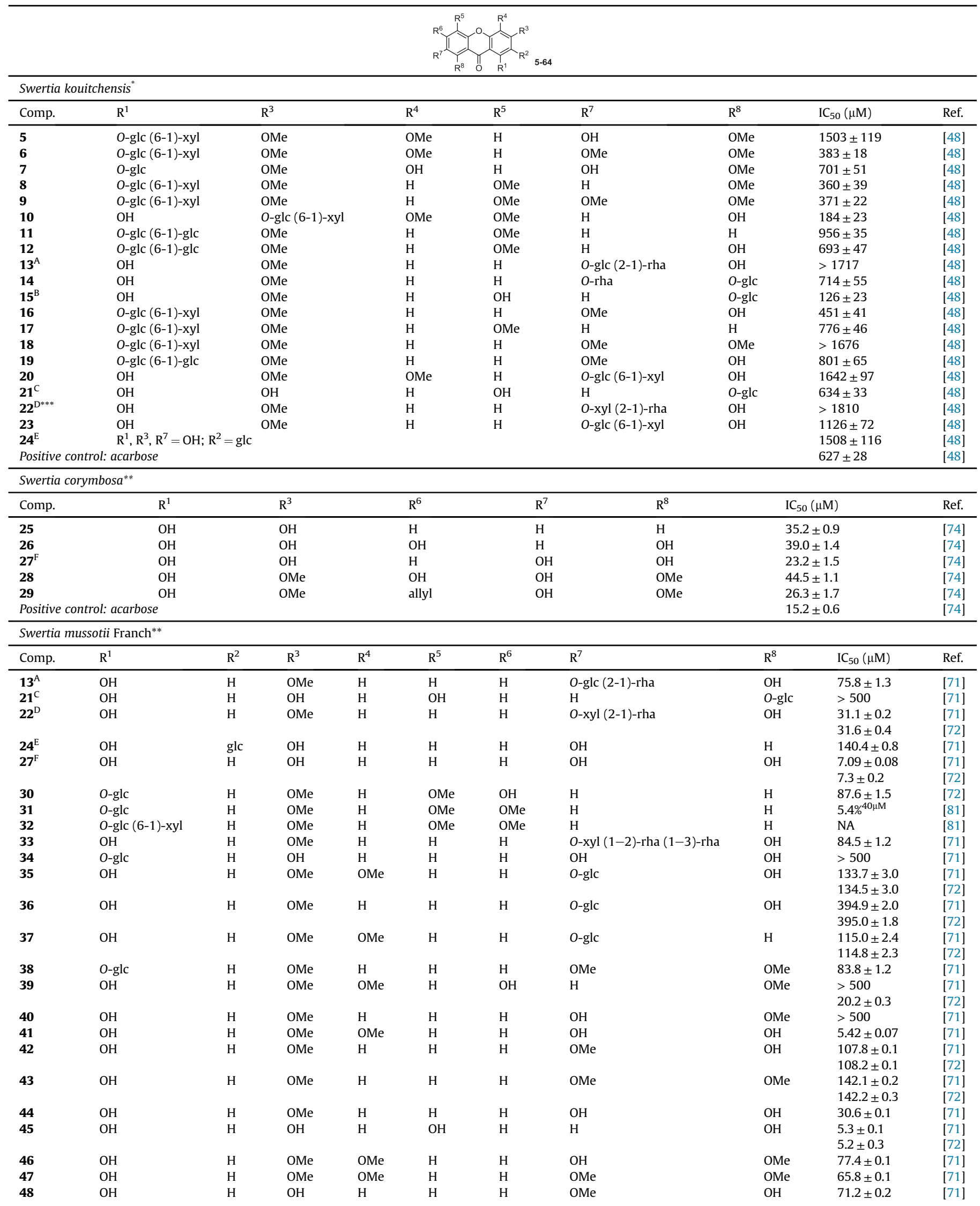


Table 3 (continued)



*Assays performed on $\alpha$-glucosidase from Saccharomyces cerevisiae.

**Assays performed on an unknown source of $\alpha$-glucosidase.

$\mathrm{A}-\mathrm{F}$ These compounds were isolated from the signed sources, presenting different $\mathrm{IC}_{50}$ values.

D***In another work, xanthone $\mathbf{2 2}$ was also tested and presented an $\mathrm{IC}_{50}=36 \mu \mathrm{M}$, with acarbose used as positive control $\left(\mathrm{IC}_{50}=24 \mu \mathrm{M}\right)$ [46].

[74]. Xanthone 27 along with xanthones 13, 21, 22, 24, and 30-54 were also obtained from whole parts of $S$. mussotii [71]. The inhibitory effect of compound $\mathbf{2 7}$, vary with its origin, S. corymbosa [74] and $S$. mussotii [71,72], showing different $\mathrm{IC}_{50} \mathrm{~S}$, $\mathrm{IC}_{50}=23.2 \pm 1.5 \mu \mathrm{M}$ in the first case and $7.09 \pm 0.08$ or $7.3 \pm 0.2 \mu \mathrm{M}$, in the second one. Even more, in the first case, this xanthone was less active than acarbose $\left(\mathrm{IC}_{50}=15.2 \pm 0.6 \mu \mathrm{M}\right)$, while in the second one, was more active than the positive control $\left(\mathrm{IC}_{50}=39.6 \pm 0.1 \mu \mathrm{M}\right)$. Nevertheless, xanthones 41 and 45 were the most active compounds from whole parts of $S$. mussotii, with $\mathrm{IC}_{50}=5.42 \pm 0.07$ and $5.3 \pm 0.1$ or $5.2 \pm 0.3 \mu \mathrm{M}$, respectively, that were considerably lower than the $\mathrm{IC}_{50}$ obtained for acarbose $\left(\mathrm{IC}_{50}=39.6 \pm 0.1 \mu \mathrm{M}\right)$. The authors also disclosed that, generally, glycosylated xanthones $(\mathbf{1 3}, \mathbf{2 1}, \mathbf{2 4}$ and 30-38) were poor inhibitors of $\alpha$-glucosidase activity, except for compound $\mathbf{2 2}$ which presented an $\mathrm{IC}_{50}=31.1 \pm 0.2 \mu \mathrm{M}$ [71]. Xanthones 31 and 32 isolated from overground parts of $S$. mussotii Franch displayed no activity, in the tested experimental conditions, in the inhibition of $\alpha$-glucosidase activity [81]. From the 13 xanthones isolated from S. bimaculata 15, $21,22,55-64$, compounds 56,62 and 64 were ineffective inhibitors against $\alpha$-glucosidase activity, whilst compounds $\mathbf{5 7}, \mathbf{5 8}$ and $\mathbf{6 1}$ were the most promising tested derivatives $\left(\mathrm{IC}_{50}=142 \pm 17\right.$, $136 \pm 14$ and $258 \pm 19 \mu \mathrm{M}$, respectively), considering the effect of the positive control acarbose $\left(\mathrm{IC}_{50}=426 \pm 45 \mu \mathrm{M}\right)$ [52]. On further analysis, it was observed that the presence of a methoxyl group located at C-2 (compounds $\mathbf{5 5}$ and $\mathbf{5 6}$ ) produced steric hindrance and lowered the inhibitory activity, when compared with the analogs without substitution at C-2 (compounds 57 and 58). In addition, it is possible to observe that the presence of the 0 -glc-(41)-glc residue at $\mathrm{C}-1$ (xanthone $\mathbf{6 1}$ ) resulted in relatively more effective inhibitory activity than the respective diglycosides $\mathbf{5 9}$ and
60 [52].

Plants of the Garcinia species (Clusiaceae family) are known to possess oxygenated and prenylated xanthones. The structures isolated from different parts of eight species (G. mangostana [44], G. nobilis [54], G. cowa [55], G. xanthochymus [62], G. oblongifolia [63], G. fusca [42], G. paucinervis [45] and G. hanburyi [49]) and their inhibitory activity against $\alpha$-glucosidase are presented in Table 4.

Among the 16 xanthones isolated from the fruit case of G. mangostana $65-80$ ( $\mathrm{IC}_{50}$ ranging from $1.5 \pm 0.1$ to $\left.63.5 \pm 1.7 \mu \mathrm{M}\right)$, only compounds $\mathbf{7 0} \quad\left(\mathrm{IC}_{50}=58.5 \pm 0.4 \mu \mathrm{M}\right), \quad \mathbf{7 1}$ $\left(\mathrm{IC}_{50}=50.5 \pm 2.8 \mu \mathrm{M}\right), \quad 75 \quad\left(\mathrm{IC}_{50}=63.5 \pm 1.7 \mu \mathrm{M}\right) \quad$ and $\quad \mathbf{8 0}$ $\left(\mathrm{IC}_{50}=45.0 \pm 0.2 \mu \mathrm{M}\right)$ exhibited $\mathrm{IC}_{50}$ values higher than the obtained for the positive control (1-deoxynojirimycin, $\left.\mathrm{IC}_{50}=39.5 \pm 0.5 \mu \mathrm{M}\right)$ while $\alpha$-mangostin 65 , mangostingone $67, \gamma$ mangostin 69 and smeathxanthone $\mathrm{A} 74$ reached $\mathrm{IC}_{50}$ values lower than $10 \mu \mathrm{M}$ (Table 4). These results indicate that the presence of free hydroxyl groups in A and B rings of the xanthone core favors the inhibitory activity of the compounds. Moreover, a comparison of prenyl and prenyl hydrate substitution revealed that prenylation displayed more efficacy for $\alpha$-glucosidase inhibition (see structures on Table 4: $\alpha$-mangostin $65, \mathrm{IC}_{50}=5.0 \pm 0.1 \mu \mathrm{M}$; mangostingone 67, $\mathrm{IC}_{50}=9.8 \pm 0.3 \mu \mathrm{M}$ vs garcinone $\left.\mathrm{D} \mathbf{6 8}, \mathrm{IC}_{50}=29.9 \pm 1.8 \mu \mathrm{M}\right)$. The same conclusion was driven by the authors when they used maltose as substrate, instead PNGP in the $\alpha$-glucosidase inhibitory activity assay, although with less potency (Table 5). Similarly, $\alpha-$ mangostin 65, $\gamma$-mangostin 69, gartanin 73 and smeathxanthone $A$ $\mathbf{7 4}$ were the more active tested compounds, with $\mathrm{IC}_{50}$ values of 53.3, $17.5,37.7$ and $35.3 \mu \mathrm{M}$, respectively, when compared with the positive control 1-deoxynorijirimycin ( $\mathrm{IC}_{50}=68.8 \mu \mathrm{M}$ ) [44]. In addition, kinetic parameters were determined using the Lineweaver-Burk double-reciprocal-plot method. The kinetic 
Table 4

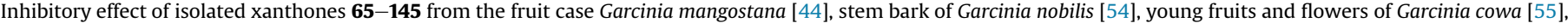


Saccharomyces cerevisiae $\alpha$-glucosidase activity.

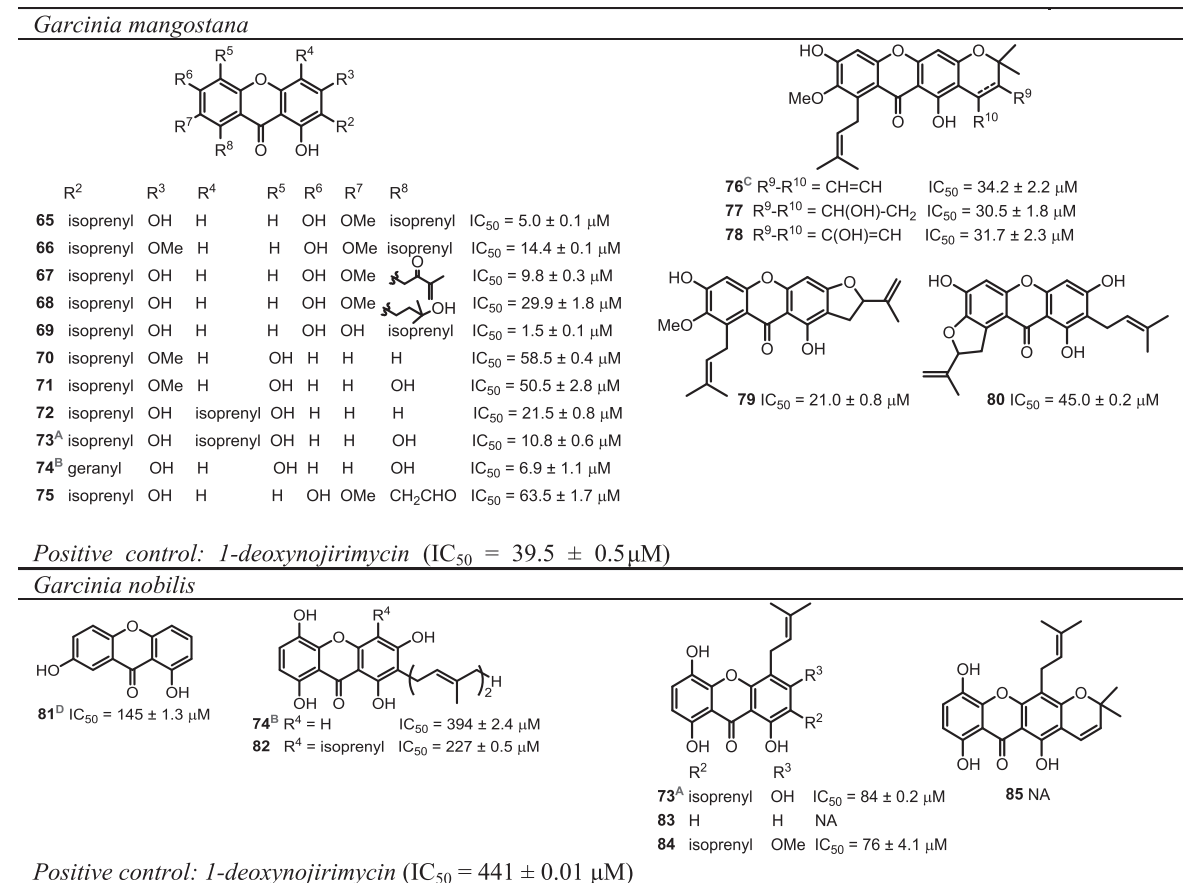

Positive control: 1 -deoxynojirimycin $\left(\mathrm{IC}_{50}=441 \pm 0.01 \mu \mathrm{M}\right.$ )
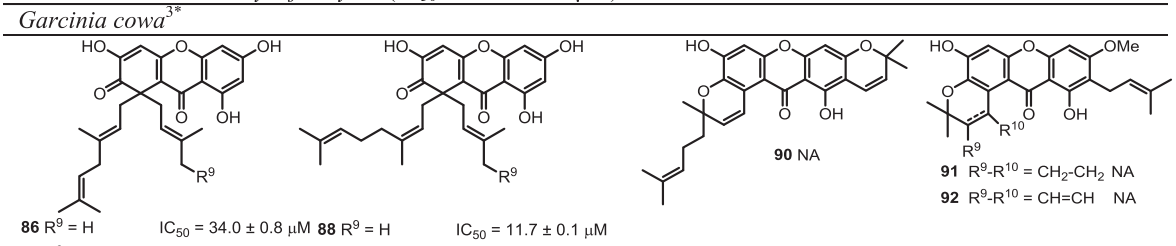

$87 R^{9}=$ isoprenyl $I C_{50}=36.4 \pm 0.5 \mu M 89 R^{9}=$ isoprenyl $I C_{50}=55.3 \pm 0.2 \mu M$





$\begin{array}{llll}\mathrm{R}^{6} & \mathrm{R}^{7} & \mathrm{R}^{8} & \mathrm{R}^{9}\end{array}$

$76^{\mathrm{C}} \mathrm{Me} \quad \mathrm{OH}$ OMe isoprenyl $\mathrm{IC}_{50}=34.6 \pm 0.2 \mu \mathrm{M}$

93 isoprenyl $\mathrm{OH}$ OMe $\mathrm{H} \quad \mathrm{NA}$

$94 \mathrm{Me} O \mathrm{OMOH}$ isoprenyl NA

$95 \mathrm{Me} \quad \mathrm{OMe}$ OMe isoprenyl $\mathrm{IC}_{50}=26.2 \pm 0.9 \mu \mathrm{M}$

$96 \mathrm{Me} \quad \mathrm{OH}$ OMe geranyl $\mathrm{IC}_{50}=18.6 \pm 0.3 \mu \mathrm{M}$
$\mathrm{R}^{2}$



$\begin{array}{lllll}\mathrm{R}^{3} & \mathrm{R}^{5} & \mathrm{R}^{6} & \mathrm{R}^{7} & \mathrm{R}^{6}\end{array}$

66 isoprenyl $\mathrm{OMe} \mathrm{H} \quad \mathrm{OH}$ OMe isoprenyl $\mathrm{IC}_{50}=8.7 \pm 0.3 \mu \mathrm{M}$

97 geranyl $\mathrm{OH} \mathrm{H}$

$\mathrm{OH}$ OMe isoprenyl $\mathrm{IC}$

$\begin{array}{lll}\mathrm{OH} & \mathrm{OMe} \mathrm{H} & \mathrm{NA} \\ \mathrm{OMe} & \mathrm{OMe} & \mathrm{H}\end{array}$

99 isoprenyl $\mathrm{OH}$ isoprenyl $\mathrm{OH}$ OMe isoprenyl NA

100 isoprenyl OMe H OH OH isoprenyl NA

$101^{\mathrm{E}} \mathrm{H} \quad \mathrm{OH} \quad \mathrm{H} \quad \mathrm{OH}$ OMe geranyl $\mathrm{IC}_{50}=23.4 \pm 0.9 \mu \mathrm{M}$

Positive control: acarbose $\left(I C_{50}=8.0 \pm 1.7 \mu M\right)$

Garcinia xanthochymus

$102 \mathrm{IC}_{50}=94.2 \pm 25.2 \mu \mathrm{M}$<smiles>[R]c1cc([R])c2oc3c(O)c4occc4cc3c(=O)c2c1O</smiles>

$106 \mathrm{OH}_{\mathrm{IC}_{50}=133.8 \pm 19.3 \mu \mathrm{M}}$

Positive control: acarbose $\left(\mathrm{IC}_{50}=9000 \pm 30 \mu \mathrm{M}\right)$

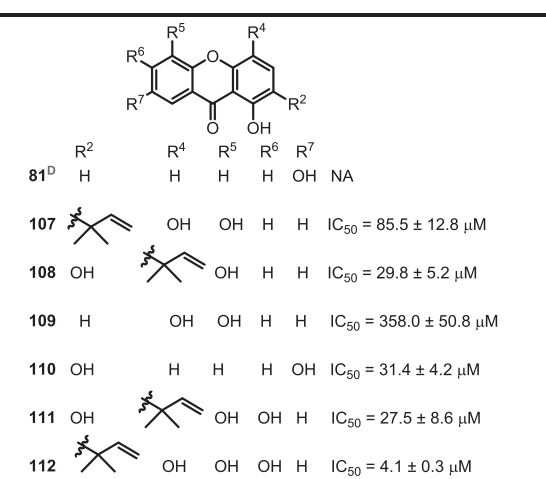




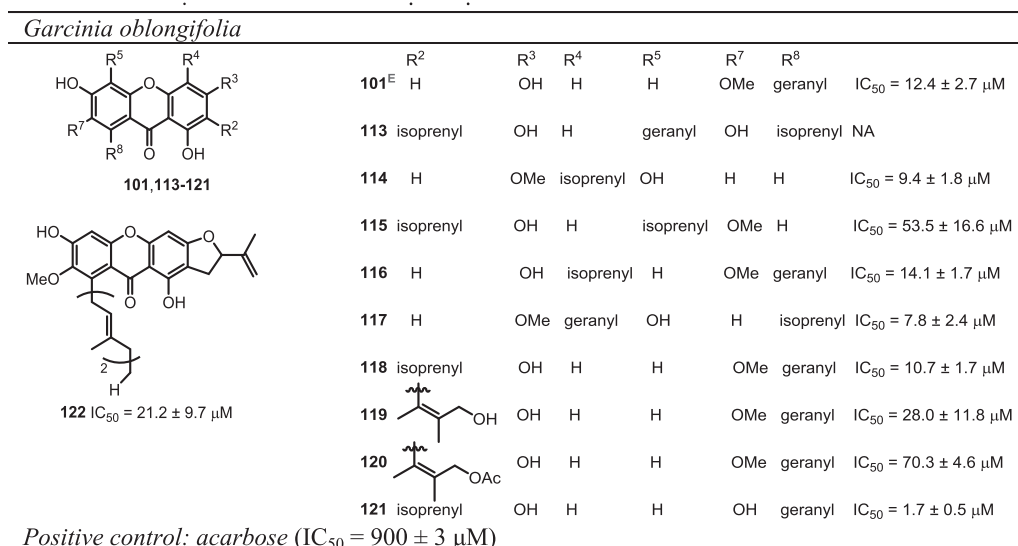

\section{Positive control: acarbose $\left(\mathrm{IC}_{50}=900 \pm 3 \mu \mathrm{M}\right)$}

Garcinia fusca

125 isoprenyl $\mathrm{H} \quad \mathrm{OMe}$ isoprenyl $\mathrm{IC}_{50}=18.2 \pm 1.5 \mu \mathrm{M}$

Positive control: acarbose $\left(\mathrm{IC}_{50}=214.5 \pm 2.3 \mu \mathrm{M}\right)$

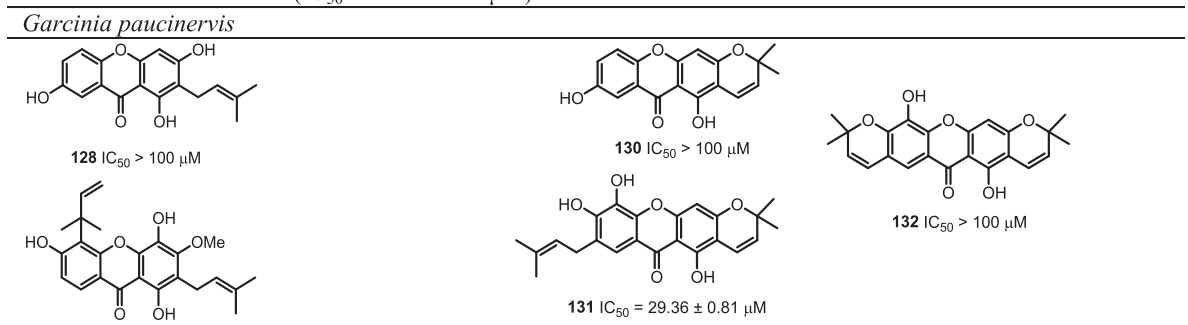

$129 \mathrm{IC}_{50}=8.90 \pm 3.35 \mu \mathrm{M}$

Positive control: acarbose $\left(\mathrm{IC}_{50}=2.88 \pm 0.85 \mu \mathrm{M}\right)$

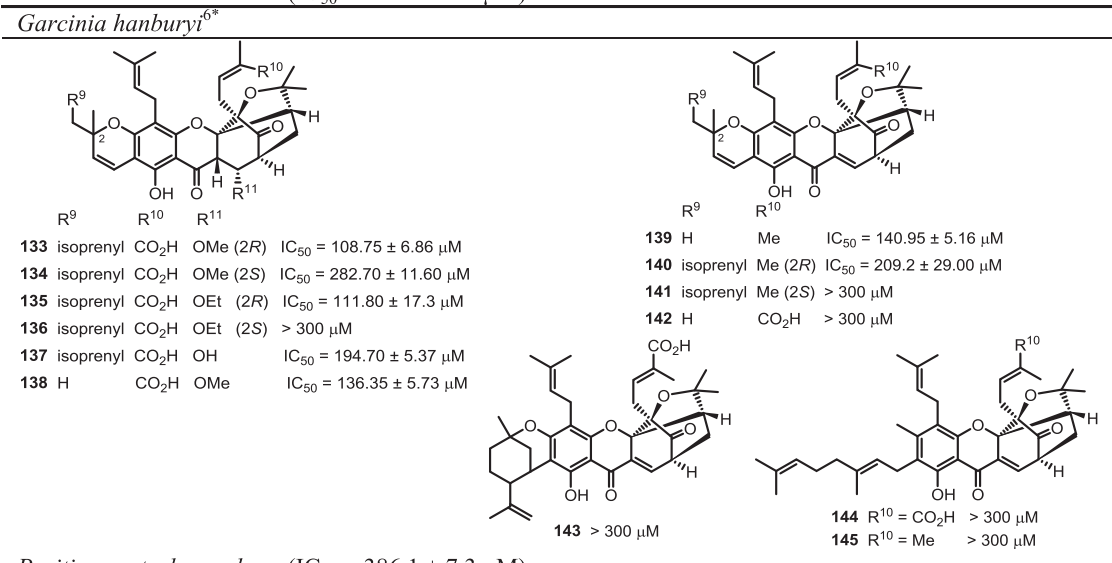

NA: no activity was found.

Positive control: acarbose $\left(\mathrm{IC}_{50}=386.1 \pm 7.3 \mu \mathrm{M}\right)$

${ }^{A-E}$ These compounds were isolated from the signed sources, presenting different $\mathrm{IC}_{50}$ values. 
Table 5

Kinetic profile of isolated xanthones $\mathbf{6 5 - 8 0}$ from the fruit case Garcinia mangostana against $\alpha$-glucosidase from Saccharomyces cerevisiae, using PNGP as substrate and inhibitory activity using maltose as substrate [44].

\begin{tabular}{|c|c|c|c|}
\hline \multirow{2}{*}{ Comp. } & \multicolumn{2}{|l|}{ PNGP } & \multirow{2}{*}{$\begin{array}{l}\text { Maltose } \\
\mathrm{IC}_{50}(\mu \mathrm{M})\end{array}$} \\
\hline & $\mathrm{K}_{\mathrm{i}}(\mu \mathrm{M})$ & Type of inhibition & \\
\hline 65 & $7.3 \pm 2.1$ & mixed & 53.3 \\
\hline 66 & $14.8 \pm 3.4$ & mixed & 192.0 \\
\hline 67 & $8.1 \pm 1.7$ & mixed & 85.7 \\
\hline 68 & NT & NT & 140.2 \\
\hline 69 & $1.4 \pm 0.1$ & mixed & 17.5 \\
\hline 70 & NT & NT & $>200$ \\
\hline 71 & NT & NT & $>200$ \\
\hline 72 & $12.3 \pm 0.4$ & mixed & 137.2 \\
\hline 73 & $8.5 \pm 0.3$ & mixed & 37.7 \\
\hline 74 & $2.8 \pm 0.3$ & mixed & 35.3 \\
\hline 75 & NT & NT & $>200$ \\
\hline 76 & NT & NT & 92.2 \\
\hline 77 & $23.0 \pm 1.5$ & mixed & 102.5 \\
\hline 78 & NT & NT & 155.6 \\
\hline 79 & $18.1 \pm 3.2$ & mixed & 191.2 \\
\hline 80 & NT & NT & $>200$ \\
\hline Positive control: 1-deoxynorijirimycin & NT & NT & 68.8 \\
\hline
\end{tabular}

NT: not tested.

assays showed that all of the tested compounds are mixed-type inhibitors (Table 5) [44]. Xanthone derivative mangostenone F 79, isolated from the fruit case of Garcinia mangostana, was tested for their inhibitory activity against a range of enzymes. Thus, against $\alpha$ glucosidase activity (from Saccharomyces cerevisiae) showed an $\mathrm{IC}_{50}=21.0 \pm 0.8 \mu \mathrm{M} \quad$ (positive control 1-deoxynorjirimycin, $\left.\mathrm{IC}_{50}=39.5 \pm 0.5 \mu \mathrm{M}\right)[44,68]$ and against $\beta$-glucosidase activity (from almond) presented an $\mathrm{IC}_{50}=212 \pm 18 \mu \mathrm{M}$, being not active to inhibit the action of enzymes such as $\alpha$-mannosidase (from jack been), $\alpha$-galactosidase (from green coffee bean), $\beta$-galactosidase (from bovine liver), $\alpha$-rhamnosidase (from Penicillium decumbens) and $\alpha$-amylase (from porcine pancreas) [68].

From the 7 xanthones isolated from stem bark of G. nobilis (Table 4), 73, 74 and $\mathbf{8 1 - 8 5}$, the derivatives 83 and 85 were inactive, while the remaining $\mathbf{7 3}, \mathbf{7 4}, \mathbf{8 1}, \mathbf{8 2}$ and 84 demonstrated higher inhibitory effects than the standard 1-deoxynojirimycin $\left(\mathrm{IC}_{50}=441 \pm 0.01 \mu \mathrm{M}\right)$. The xanthones gartanin $73 \quad\left(\mathrm{IC}_{50}\right.$ $84 \pm 0.2 \mu \mathrm{M})$ and 8-hydroxycudraxanthone G $84\left(\mathrm{IC}_{50} 76 \pm 4.1 \mu \mathrm{M}\right)$ were the most active compounds [54]. Comparing the data obtained for compounds $\mathbf{7 3}$ and $\mathbf{7 4}$ isolated from G. mangostana and G. nobilis, we can state that both xanthones are more active than the positive control of each assay (respectively $\mathrm{IC}_{50}=39.5 \pm 0.5$ and $441 \pm 0.01 \mu \mathrm{M})$; however, the reported $\mathrm{IC}_{50}$ values were quite different between the authors being, respectively, of $10.8 \pm 0.6$ and $6.9 \pm 1.1 \mu \mathrm{M}$ for $G$. mangostana [44] and $84 \pm 0.2$ and $394 \pm 2.4 \mu \mathrm{M}$ for G. nobilis [54] (Table 4).

According to Table 4, among the nineteen xanthones identified in young fruits and flowers of $G$. cowa $(65,66,76$ and 86-101), it was only possible to determine the $\mathrm{IC}_{50}$ value of ten derivatives. $\alpha$ Mangostin $65\left(\mathrm{IC}_{50} 7.8 \pm 0.5 \mu \mathrm{M}\right)$ and $\beta$-mangostin 66 ( IC 50 $8.7 \pm 0.3 \mu \mathrm{M})$ exhibited the highest $\alpha$-glucosidase inhibitory activity, similar to the positive control acarbose ( $\mathrm{IC}_{50}=8.0 \pm 1.7 \mu \mathrm{M}$ ). The other tested compounds were less effective, with $\mathrm{IC}_{50}$ values ranging from $11.7 \pm 0.1$ to $55.3 \pm 0.2 \mu \mathrm{M}$ [55]. The 12 xanthones 81 and 102-112 isolated from the bark of $G$. xanthochymus exhibited a strong activity in the inhibition of $\alpha$-glucosidase, except for compounds 81 and 104 which were inactive in this assay. Subelliptenone $\mathrm{F} 112$ was the most active one $\left(\mathrm{IC}_{50}=4.1 \pm 0.3 \mu \mathrm{M}\right)$ whilst IC 50 values from $27.5 \pm 8.6$ to $358.0 \pm 50.8 \mu \mathrm{M}$ were observed for the remaining xanthones, values lower than those obtained for the positive control acarbose $\left(\mathrm{IC}_{50}=900.0 \pm 3.0 \mu \mathrm{M}\right)$ [62]. The main feature of derivative $\mathbf{1 1 2}$ is the presence of a 1,4,5,6- tetrahydroxylated substitution pattern (possessing a catechol ring system) and a 1,1-dimethylallyl moiety at C-2. In the absence of the catechol ring system, the activity decreased, as observed in compounds $103\left(\mathrm{IC}_{50}=36.7 \pm 20.0 \mu \mathrm{M}\right), \mathbf{1 0 7}\left(\mathrm{IC}_{50}=85.5 \pm 12.8 \mu \mathrm{M}\right)$ and $105\left(\mathrm{IC}_{50}=142.3 \pm 10.8 \mu \mathrm{M}\right)$. Moreover, the 1,1-dimethylallyl side chain located at C-2 in 1,4,5-trihydroxyylated xanthone core (107, $\mathrm{IC}_{50}=85.5 \pm 12.8 \mu \mathrm{M}$ ) seemed to enhance the inhibitory activity when compared with the 1,4,5-trihydroxyxanthone $\mathbf{1 0 9}$ $\left(\mathrm{IC}_{50}=358.0 \pm 50.8\right)$ [62]

With the exception of compound 113, the isolated compounds from twigs of G. oblongifolia $\mathbf{1 0 1}$ and 114-122 were good inhibitors of $\alpha$-glucosidase activity presenting $\mathrm{IC}_{50}$ values ranging from $1.7 \pm 0.5$ to $70.3 \pm 4.6 \mu \mathrm{M}$, significantly lower than the $\mathrm{IC}_{50}$ obtained for acarbose, $\mathrm{IC}_{50}=900 \pm 3 \mu \mathrm{M}$ [63]. Another detail is observed for rubraxanthone 101, that showed an $\mathrm{IC}_{50}$ value of $12.4 \pm 2.7 \mu \mathrm{M}$ [63], lower than that previously reported for this compound isolated from G. cowa $\left(\mathrm{IC}_{50}=23.4 \pm 0.9 \mu \mathrm{M}\right)$ (Table 4) [55].

Nguyen et al. isolated from the roots of $G$. fusca a series of ten xanthones 65, 97, 118-120 and 123-127 carrying isoprenyl- or geranyl-type side chains attached to a polyoxygenated xanthone core (Table 4) [42]. All compounds inhibited $\alpha$-glucosidase activity in a more efficient manner ( $\mathrm{IC}_{50}$ values varying from $8.3 \pm 1.8$ to $168.7 \pm 1.5 \mu \mathrm{M})$ than the positive control acarbose $\left(\mathrm{IC}_{50}=214.5 \pm 2.3 \mu \mathrm{M}\right)$. Fuscaxanthons $\mathrm{J} 123$ was the most active one with an $\mathrm{IC}_{50}$ value of $8.3 \pm 1.8 \mu \mathrm{M}$ followed by $\alpha$-mangostin 65 $\left(\mathrm{IC}_{50}=11.4 \pm 2.3 \mu \mathrm{M}\right)$. The presence of a prenyl group instead of a geranyl side chain located at C-8 played an important role for a strong $\alpha$-glucosidase inhibitory activity $(\mathbf{6 5}$, $\mathrm{IC}_{50}=11.4 \pm 2.3 \mu \mathrm{M}<\mathbf{1 1 8}, \quad \mathrm{IC}_{50}=20.7 \pm 1.5 \mu \mathrm{M}$ ), whilst the presence of a methoxy group at C-6 decreased the activity (65, $\left.\mathrm{IC}_{50}=11.4 \pm 2.3 \mu \mathrm{M}<\mathbf{1 2 5}, \quad \mathrm{IC}_{50}=18.2 \pm 1.5 \mu \mathrm{M}\right) . \quad$ Moreover, xanthone 123, with a hydroxy group at C-6 and an isoprenyl side chain at $C-5$, showed a higher inhibitory effect than xanthone 124, which has a methoxy group located at C-6 and does not possess the C-5 unit (Table 4) [42].

From the 5 xanthones isolated from the leaves of G. paucinervis 128-132, none of them exhibited higher inhibition of $\alpha$-glucosidase activity than the positive control acarbose $\left(\mathrm{IC}_{50}=2.88 \pm 0.85 \mu \mathrm{M}\right)$. Compounds 129 and 131 displayed moderate inhibitory activity with $\mathrm{IC}_{50}$ values of $8.90 \pm 3.35$ and $29.36 \pm 0.81 \mu \mathrm{M}$, respectively. The remaining derivatives were ineffective, with $\mathrm{IC}_{50}>100 \mu \mathrm{M}$ (Table 4) [45]. 
Apart from the highly diverse number of xanthones already described, 13 caged polyprenylated derivatives 133-145 have been isolated from the resin of $G$. hanburyi with a unique 4-oxatricyclo [4.3.1.0]dec-2-one scaffold and tested for their $\alpha$-glucosidase inhibitory activity (Table 4). Compounds 133-135 and 137-140 showed inhibitory effects with $\mathrm{IC}_{50}$ values varying from $108.75 \pm 6.86$ to $282.70 \pm 11.60 \mu \mathrm{M}$ whilst compounds 136 and 141-145 presented $\mathrm{IC}_{50}>300 \mu \mathrm{M}$ (acarbose, $\mathrm{IC}_{50}=386.1 \pm 7.3 \mu \mathrm{M}$ ) [49].

Moreover, a recent review highlighted the pharmacological effects of Garcinia mangostana and its xanthones in the control and modification of metabolic syndrome and its related disorders such as obesity, hyperglycemia, dyslipidemia, diabetic and inflammatory complications in experimental in vitro and in vivo studies [83].

Oxygenated and prenylated xanthones are not restricted to the Garcinia species. A wide variety of derivatives have been isolated from other natural sources, which inhibitory effects against $\alpha$ glucosidase activity are depicted in Table 6 [41,43,47,50,51,53]. Eight xanthones 146-153 have been isolated from the roots of Cudrania tricuspidata and among them seven derivatives have $\mathrm{IC}_{50}$ values ranging from $16.2 \pm 0.4$ to $52.9 \pm 2.1 \mu \mathrm{M}$ (Table 6) [43]. Xanthone 153 was the most active compound ( $\left.\mathrm{IC}_{50} 16.2 \pm 0.4 \mu \mathrm{M}\right)$ while the derivative $\mathbf{1 5 0}$ was ineffective at the highest tested concentration $(100 \mu \mathrm{M})$. Generally, these derivatives are moderate inhibitors when compared to the positive controls used in this assay: voglibose $\left(\mathrm{IC}_{50}=23.4 \mu \mathrm{M}\right)$ and 1-deoxynojirimycin $\left(\mathrm{IC}_{50}=3.5 \mu \mathrm{M}\right)$. The authors also analyzed the inhibitory kinetic profile of compounds 146-149 and 141-153 using Lineweaver-Burk plots, and showed that all xanthones displayed a mixed type inhibition (Table 7). Moreover, increasing the inhibitor concentration, in a plot of the reaction velocity as a function of the substrate concentration, lowered the slope of the resultant line, which pointed out a reversible inhibitor behavior [43].

A series of eleven hydroxylated and methoxylated xanthones 50, 81 and 154-162 has been isolated from the stem of Securidaca inappendiculata and showed, apart from xanthone 161, a strong $\alpha$ glucosidase inhibition with $\mathrm{IC}_{50}$ values ranging from 3.2 to $77.3 \mu \mathrm{g} /$ $\mathrm{mL}$ (acarbose, $\mathrm{IC}_{50}=735 \mu \mathrm{g} / \mathrm{mL}$ ) (Table 6) [50]. Corroborating what was already reported $[41,56,60]$, the authors concluded that the presence of more hydroxyl groups attached to the xanthone nucleus are beneficial to the activity (when compared the higher $\mathrm{IC}_{50}$ value of the compound $\mathbf{8 1}$ and 158, which possess two hydroxyl groups, with those of the compounds $\mathbf{5 0}$ and 156, with three hydroxyl groups). Nine out of the eleven xanthones inhibited $\alpha$ glucosidase activity in a noncompetitive reversible manner, evidenced by the intersection of the double reciprocal plots seated on the $\mathrm{xx}$ axis. On the other hand, the derivative $\mathbf{1 5 5}$ seems to be a competitive reversible inhibitor type [50].

From all the xanthone-type compounds 163-170 isolated from the twigs of Maclura fruticosa, none of them exhibited inhibitory activity against $\alpha$-glucosidase, at the tested experimental conditions (Table 6) [47]. Recently, Li et al. isolated from the root barks of Cratoxylum cochinchinense a series of twelve prenyl-type polyoxygenated xanthones 65, 69, 127 and 171-179 and tested their $\alpha$ glucosidase inhibitory activity and kinetic profile [24]. Apart from the derivative $179\left(\mathrm{IC}_{50}=72.2 \mu \mathrm{M}\right)$, all xanthones were better inhibitors, with $\mathrm{IC}_{50}$ ranging from 1.7 to $30.7 \mu \mathrm{M}$, than the positive control deoxynojirimycin $\left(\mathrm{IC}_{50}=39.5 \mu \mathrm{M}\right)$. The most active xanthones were $\alpha$-mangostin $65\left(\mathrm{IC}_{50}=5.7 \mu \mathrm{M}\right), \gamma$-mangostin 69 $\left(\mathrm{IC}_{50}=1.7 \mu \mathrm{M}\right)$ and caratoxanthone $\mathrm{A} 171\left(\mathrm{IC}_{50}=4.8 \mu \mathrm{M}\right)$, presenting the derivatives 65 and 69 similar inhibitory effects to those reported when the compounds were isolated from $G$. mangostana (respectively, $\mathrm{IC}_{50}=5.0 \pm 0.1$ and $1.5 \pm 0.1 \mu \mathrm{M}$ ) [44]. According to the obtained results, increasing the number of free hydroxyl groups attached to the xanthone nucleus, favours the inhibitory effect (comparing $\gamma$-mangostin $\mathbf{6 9}$ with four hydroxyl groups with the other tested compounds which possessed three or two hydroxyl groups). The replacement of a hydroxyl by a methoxy group lowered the inhibitory effect $\left(\mathrm{IC}_{50} \gamma\right.$-mangostin $\mathbf{6 9}<\mathrm{IC}_{50} \alpha$-mangostin 65) (Table 6) [41]. The authors also analyzed the inhibitory kinetic profile of all isolated xanthones using Lineweaver-Burk plots, showing all the compounds a mixed type inhibition (Table 7). Moreover, increasing the concentration of the inhibitor in plots of the initial velocity $v s$ substrate concentrations, results in a decrease of the slope of the line, indicating that these compounds were reversible inhibitors [41].

A group of seven xanthone-type compounds 180-186 isolated from the cultures of Aspergillus versicolor, a fungal endophyte of Huperzia serrate was screened against their ability to inhibit $\alpha$ glucosidase activity. Thus, derivative $\mathbf{1 8 3}$ showed a higher efficacy $\left(\mathrm{IC}_{50}=0.26 \mathrm{mM}\right)$ than the positive control acarbose $\left(\mathrm{IC}_{50}=0.38 \mathrm{mM}\right)$, whilst xanthone $184\left(\mathrm{IC}_{50}=2.98 \mathrm{mM}\right)$ showed a weak inhibition. However, these results should be carefully analyzed due to the absence of errors associated with the $\mathrm{IC}_{50}$ values. The remaining compounds were completely inactive against $\alpha$-glucosidase activity, in the tested experimental conditions (Table 6) [53]. A single xanthone 187, isolated from deep-seaderived fungus Penicillium chrysogenum SCSIO 41001, showed a potent inhibitory effect against $\alpha$-glucosidase activity, presenting an $\mathrm{IC}_{50}=0.04 \mathrm{mM}$, significantly lower than the positive control acarbose $\left(\mathrm{IC}_{50}=0.28 \mathrm{mM}\right.$ ) (Table 6) [51].

Since 2006, a huge library of xanthone derivatives has been designed and synthesized in order to evaluate their $\alpha$-glucosidase inhibitory activity. Liu et al. prepared thirty xanthones (derivatives 25, 26, 50 and 188-214) possessing hydroxyl substituents, as well as, their acetoxy and alkoxy derivatives (Table 8) [56]. 1,3,7Trihydroxyxanthone $\mathbf{5 0}$ and 1,3,6,8-tetrahydroxyxanthone $\mathbf{2 6}$ with $\mathrm{IC}_{50}=14.7$ and $17.1 \mu \mathrm{M}$, respectively, were the most active compounds. The parent xanthone 1 was also tested, but showed no inhibitory effect with an $\mathrm{IC}_{50}>200 \mu \mathrm{M}$. According to the results, polyhydroxyxanthones 25, 26, 50 and 188-192 showed higher inhibitory activities than the corresponding acetoxy- 193-197 and alkoxyxanthones 198-214. Thus, the presence of hydroxyl groups in the xanthone core was crucial for the inhibitory activity and the efficacy is dependent on the number of hydroxyl groups: tetrahydroxyl (xanthone 26) $\approx$ trihydroxyl (xanthone 50) $>$ dihydroxyl (xanthones 25, 189 and 190) $>$ monohydroxyl (xanthone 188). In addition, the presence of straight alkoxyl, heterocyclic or hydroxylalkoxyl side chains located at C-3 (compounds 193-214) was not essential for improving the inhibitory activity of xanthones, these compounds being less actives than the positive control, 1deoxynojirimycin $\left(\mathrm{IC}_{50}=26.4 \mu \mathrm{M}\right)$ (Table 8) [56].

One year later, the same group prepared six 1,3dihydroxybenzoxanthones 215-220 and the results showed an enhanced inhibitory activity ( $\mathrm{IC}_{50}$ values ranging from 5.8 to $39.9 \mu \mathrm{M})$, when compared with 1,3-dihydroxyxanthone 25 ( IC $_{50}=160.8 \mu \mathrm{M}$, Table 8 ) and even better than the positive control, 1-deoxynojirimycin $\left(\mathrm{IC}_{50}=26.4 \mu \mathrm{M}\right)$, except for xanthones 218 $\left(\mathrm{IC}_{50}=31.3 \mu \mathrm{M}\right)$ and $220\left(\mathrm{IC}_{50}=39.9 \mu \mathrm{M}\right)$ (Table 9). The authors postulate that, the extended $\pi$-conjugated systems of benzoxanthones 215-220 play an important role to enhance the inhibitory activity, probably through $\pi$-stacking interaction with yeast's glucosidase [57]. Moreover, the inhibitory and binding mechanisms of 1,3-dihydroxyxanthone $\mathbf{2 5}$ and 1,3,7-trihydroxyxanthone $\mathbf{5 0}$ toward yeast's $\alpha$-glucosidase activity were elucidated by experimental and docking studies, which indicate a noncompetitive type of inhibition for both xanthones, with loss of $\alpha$-helix within the secondary structure of $\alpha$-glucosidase, an important feature for the inhibitory process [58]. Furthermore, a synergistic effect of these two compounds were observed, suggesting that there may exist 
Table 6

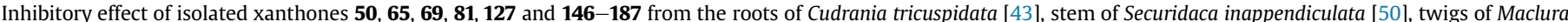

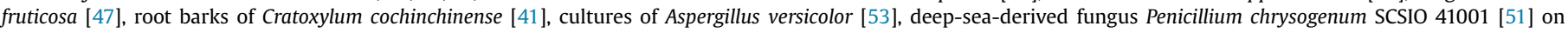
Saccharomyces cerevisiae $\alpha$-glucosidase activity.

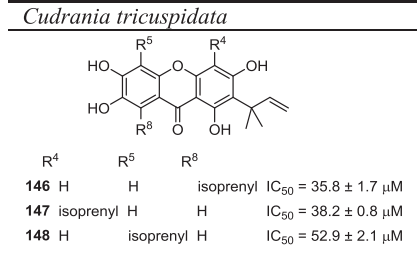

$\mathrm{R}^{4}$

150

isoprenyl > $>100 \mu \mathrm{M} \quad 152 \mathrm{R}^{3}=\mathrm{OH} \quad \mathrm{IC}_{50}=37.7 \pm 1.8 \mu \mathrm{M}$

Positive controls: voglibose $\left(I C_{50}=23.4 \mu \mathrm{M}\right), 1$-deoxynojirimycin $\left(I C_{50}=3.5 \mu \mathrm{M}\right)$

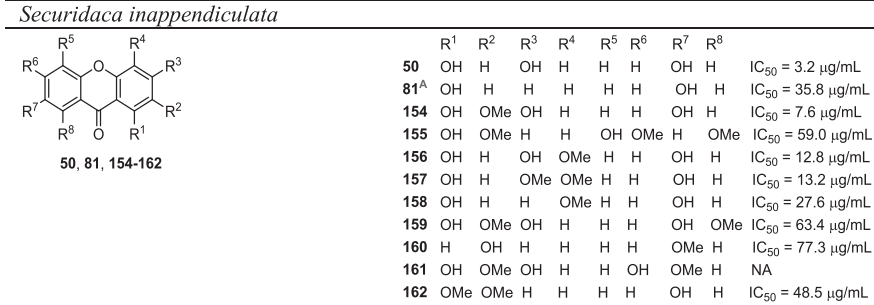

Positive control: acarbose $\left(I C_{50}=735 \mu \mathrm{g} / \mathrm{mL}\right)$

$162 \mathrm{OMe} \mathrm{OMe} \mathrm{H} \mathrm{H} \quad \mathrm{H} \quad \mathrm{H} \quad \mathrm{OH} \quad \mathrm{H} \quad \mathrm{IC}_{50}=48.5 \mu \mathrm{g} / \mathrm{mL}$

Positive control: acarbose $\left(I C_{50}=1.55 \pm 0.39 \mathrm{mM}\right)$

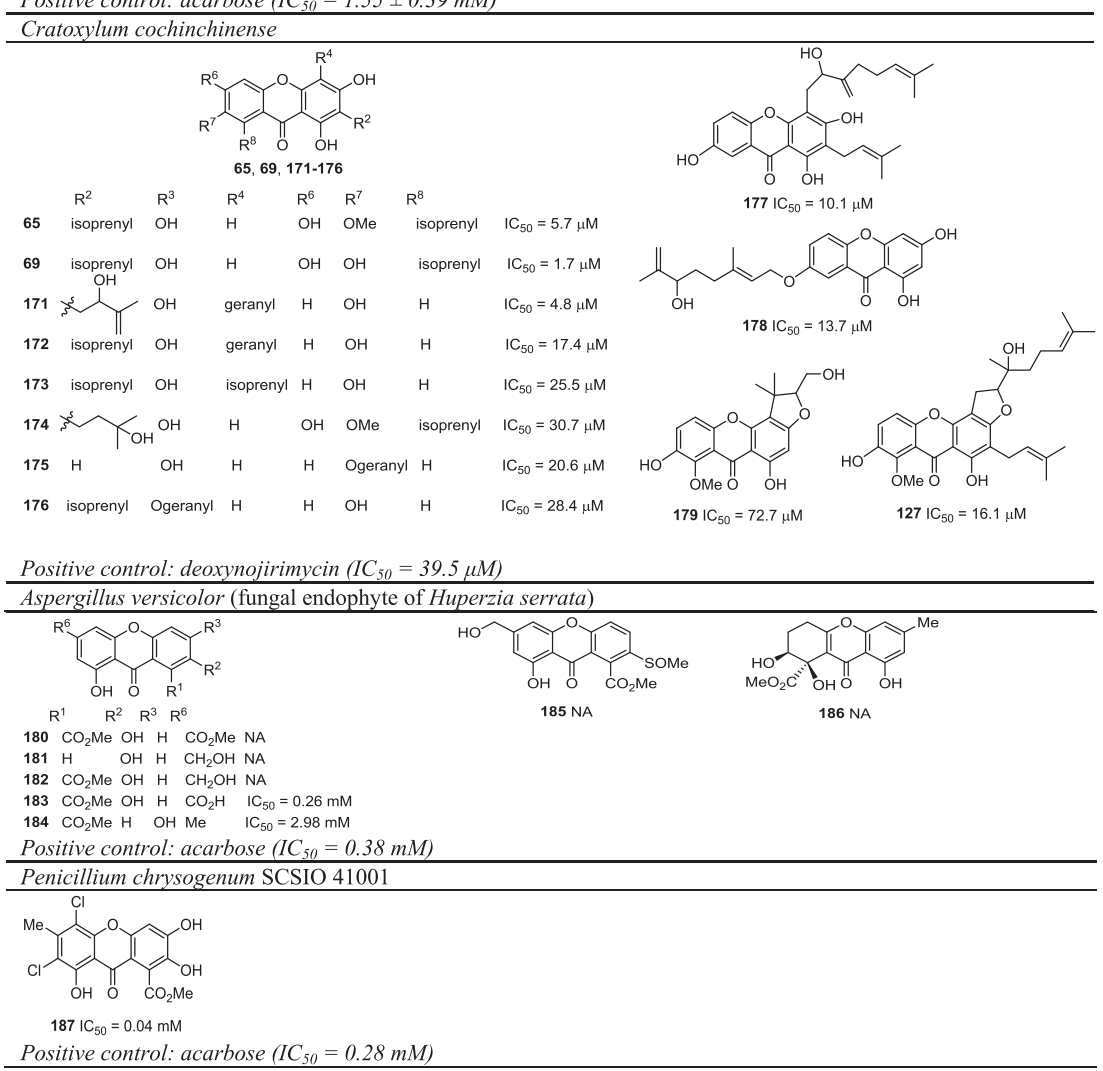

NA: no activity was found. NT: not tested.


glucosidase activity [positive controls used in this assay were deoxynojirimycin $\left(\mathrm{IC}_{50}=425.6 \pm 8.14 \mu \mathrm{M}\right)$ and acarbose $\left.(\mathrm{IC} 50=78 \pm .28 \mu \mathrm{M})\right][40]$. 
Table 7

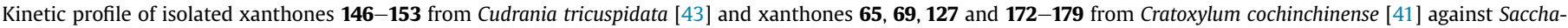
romyces cerevisiae $\alpha$-glucosidase.

\begin{tabular}{|c|c|c|c|c|c|}
\hline \multirow[t]{2}{*}{ Comp. } & \multicolumn{2}{|c|}{ Cudrania tricuspidata } & \multirow[t]{2}{*}{ Comp. } & \multicolumn{2}{|c|}{ Cratoxylum cochinchinense } \\
\hline & PNGP $K_{i}(\mu \mathrm{M})$ & Type of inhibition & & PNGP $K_{i}(\mu M)$ & Type of inhibition \\
\hline 146 & 31.7 & mixed & 65 & 7.3 & mixed \\
\hline 147 & 8.9 & mixed & 69 & 1.4 & mixed \\
\hline 148 & 7.4 & mixed & 127 & 9.9 & mixed \\
\hline 149 & 5.8 & mixed & 171 & 4.2 & mixed \\
\hline 150 & NT & NT & 172 & 13.4 & mixed \\
\hline 151 & 15.7 & mixed & 173 & 19.2 & mixed \\
\hline 152 & 12.4 & mixed & 174 & 25.1 & mixed \\
\hline \multirow[t]{5}{*}{153} & 7.0 & mixed & 175 & 17.7 & mixed \\
\hline & & & 176 & 27.2 & mixed \\
\hline & & & 177 & 8.2 & mixed \\
\hline & & & 178 & 13.0 & mixed \\
\hline & & & 179 & 33.9 & mixed \\
\hline Positive control: 1-deoxynorijirimycin & NT & & & & \\
\hline
\end{tabular}

NT: not tested.

Table 8

Inhibitory effect of synthetic xanthones $\mathbf{1}, \mathbf{2 5}, \mathbf{2 6}, \mathbf{5 0}$ and $\mathbf{1 8 8}-\mathbf{2 1 4}$ on baker's yeast $\alpha$-glucosidase activity [56].

\begin{tabular}{|c|c|c|c|c|c|c|}
\hline Comp. & $\mathrm{R}^{1}$ & $\mathrm{R}^{3}$ & $\mathrm{R}^{6}$ & $\mathrm{R}^{7}$ & $\mathrm{R}^{8}$ & $\mathrm{IC}_{50}(\mu \mathrm{M})$ \\
\hline 1 & $\mathrm{H}$ & $\mathrm{H}$ & $\mathrm{H}$ & $\mathrm{H}$ & $\mathrm{H}$ & $>200$ \\
\hline 25 & $\mathrm{OH}$ & $\mathrm{OH}$ & $\mathrm{H}$ & $\mathrm{H}$ & $\mathrm{H}$ & 160.8 \\
\hline 26 & $\mathrm{OH}$ & $\mathrm{OH}$ & $\mathrm{OH}$ & $\mathrm{H}$ & $\mathrm{OH}$ & 17.1 \\
\hline 50 & $\mathrm{OH}$ & $\mathrm{OH}$ & $\mathrm{H}$ & $\mathrm{OH}$ & $\mathrm{H}$ & $14.7^{\mathrm{a}}$ \\
\hline 188 & $\mathrm{OH}$ & $\mathrm{H}$ & $\mathrm{H}$ & $\mathrm{H}$ & $\mathrm{H}$ & 177.4 \\
\hline 189 & $\mathrm{OH}$ & $\mathrm{H}$ & $\mathrm{H}$ & $\mathrm{H}$ & $\mathrm{OH}$ & 91.5 \\
\hline 190 & $\mathrm{OH}$ & $\mathrm{H}$ & $\mathrm{OH}$ & $\mathrm{H}$ & $\mathrm{H}$ & 131.4 \\
\hline 191 & $\mathrm{OH}$ & $\mathrm{OH}$ & $\mathrm{H}$ & $\mathrm{H}$ & $\mathrm{OH}$ & 81.8 \\
\hline 192 & $\mathrm{OH}$ & $\mathrm{OH}$ & $\mathrm{OH}$ & $\mathrm{H}$ & $\mathrm{H}$ & 41.5 \\
\hline 193 & $\mathrm{OAC}$ & OAC & $\mathrm{H}$ & $\mathrm{H}$ & $\mathrm{H}$ & 31.9 \\
\hline 194 & OAC & $\mathrm{H}$ & $\mathrm{H}$ & $\mathrm{H}$ & $\mathrm{H}$ & $>200$ \\
\hline 195 & $\mathrm{OAC}$ & $\mathrm{H}$ & OAC & $\mathrm{H}$ & $\mathrm{H}$ & 138.9 \\
\hline 196 & $\mathrm{OAC}$ & OAC & $\mathrm{H}$ & OAC & $\mathrm{H}$ & 46.5 \\
\hline 197 & OAC & OAC & OAC & $\mathrm{H}$ & OAC & 49.7 \\
\hline 198 & $\mathrm{OH}$ & OMe & $\mathrm{H}$ & $\mathrm{H}$ & $\mathrm{H}$ & 172.9 \\
\hline 199 & $\mathrm{OH}$ & OEt & $\mathrm{H}$ & $\mathrm{H}$ & $\mathrm{H}$ & 110.8 \\
\hline 200 & $\mathrm{OH}$ & $\mathrm{OBu}$ & $\mathrm{H}$ & $\mathrm{H}$ & $\mathrm{H}$ & 130.1 \\
\hline 201 & $\mathrm{OH}$ & Opentyl & $\mathrm{H}$ & $\mathrm{H}$ & $\mathrm{H}$ & 120.9 \\
\hline 202 & $\mathrm{OH}$ & Oheptyl & $\mathrm{H}$ & $\mathrm{H}$ & $\mathrm{H}$ & 113.8 \\
\hline 203 & $\mathrm{OH}$ & Ooctyl & $\mathrm{H}$ & $\mathrm{H}$ & $\mathrm{H}$ & 123.7 \\
\hline 204 & $\mathrm{OH}$ & Odecayl & $\mathrm{H}$ & $\mathrm{H}$ & $\mathrm{H}$ & 115.6 \\
\hline 205 & $\mathrm{OH}$ & $\mathrm{OBn}$ & $\mathrm{H}$ & $\mathrm{H}$ & $\mathrm{H}$ & 98.2 \\
\hline 206 & $\mathrm{OH}$ & $\vec{x}_{0}$ & $\mathrm{H}$ & $\mathrm{H}$ & $\mathrm{H}$ & 66.6 \\
\hline 207 & $\mathrm{OH}$ & & $\mathrm{H}$ & $\mathrm{H}$ & $\mathrm{H}$ & 53.0 \\
\hline 208 & $\mathrm{OH}$ & & $\mathrm{H}$ & $\mathrm{H}$ & $\mathrm{H}$ & 115.4 \\
\hline 209 & $\mathrm{OH}$ & & $\mathrm{H}$ & $\mathrm{H}$ & $\mathrm{H}$ & 61.8 \\
\hline 210 & $\mathrm{OH}$ & s. & $\mathrm{H}$ & $\mathrm{H}$ & $\mathrm{H}$ & $>200$ \\
\hline 211 & $\mathrm{OH}$ & & $\mathrm{H}$ & $\mathrm{H}$ & $\mathrm{H}$ & $>200$ \\
\hline 212 & $\mathrm{OH}$ & $\mathrm{H}$ & $\mathrm{s}_{0}$ & $\mathrm{H}$ & $\mathrm{H}$ & 63.5 \\
\hline 213 & $\mathrm{OH}$ & $\mathrm{H}$ & & $\mathrm{H}$ & $\mathrm{H}$ & 132.7 \\
\hline 214 & $\mathrm{OH}$ & $\mathrm{H}$ & जू० & $\mathrm{H}$ & $\mathrm{H}$ & $>200$ \\
\hline \multicolumn{6}{|c|}{ Positive control: 1-deoxynojirimycin } & 26.4 \\
\hline
\end{tabular}

${ }^{\mathrm{a}}$ In another work, 1,3,7-trihydroxyxanthone $\mathbf{5 0}$ presented an $\mathrm{IC}_{50}=14.7 \pm 1.1 \mu \mathrm{M}$, with 1-deoxynojirimycin used as positive control $\left(\mathrm{IC}_{50}=26.4 \mu \mathrm{M}\right)$ [58]. 
Table 9

Inhibitory effect of synthetic compounds 215-229 on baker's yeast $\alpha$-glucosidase activity [57,59].

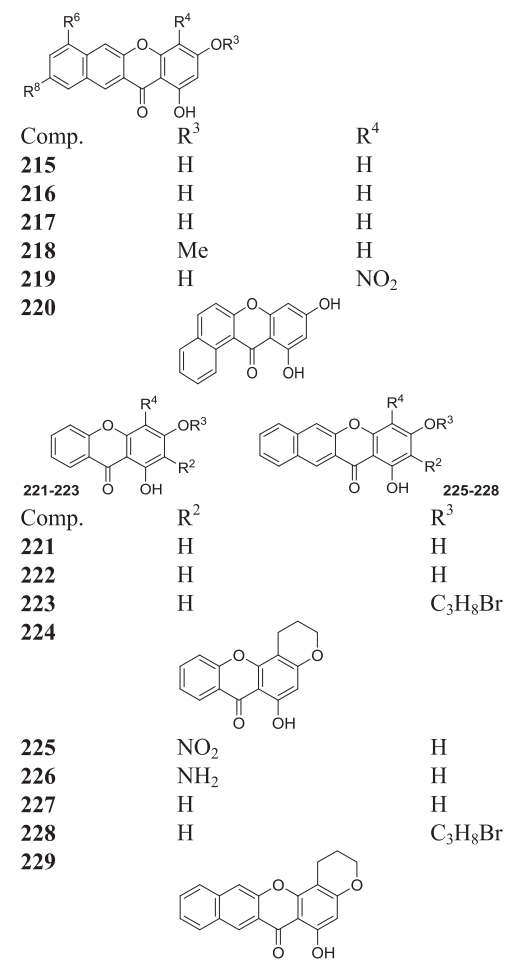

Positive control: 1-deoxynojirimycin

$\begin{array}{lll}\mathrm{R}^{6} & \mathrm{R}^{8} & \mathrm{IC}_{50}(\mu \mathrm{M}) \\ \mathrm{H} & \mathrm{H} & 9.3^{\mathrm{a}} \\ \mathrm{H} & \mathrm{OH} & 5.8 \\ \mathrm{OH} & \mathrm{H} & 8.0 \\ \mathrm{H} & \mathrm{H} & 31.3 \\ \mathrm{H} & \mathrm{H} & 20.1 \\ & & 39.9\end{array}$

$\begin{array}{ll}\mathrm{R}^{4} & \mathrm{IC}_{50}(\mu \mathrm{M}) \\ \mathrm{NO}_{2} & 235.2 \\ \mathrm{NH}_{2} & 102.3 \\ \mathrm{H} & 146.6 \\ & 198.1\end{array}$

$\mathrm{H}$

$\mathrm{H}$

$\mathrm{NH}_{2}$

$\mathrm{H} \quad 29.7$

${ }^{\mathrm{a}}$ In another work, compound 215 presented an $\mathrm{IC}_{50}$ value of $9.3 \pm .4 \mu \mathrm{M}$, with 1 -deoxynojirimycin $\left(\mathrm{IC} \mathrm{C}_{50}=26.4 \mu \mathrm{M}\right)$ as positive control [57].

multiple binding sites in the noncompetitive domain of $\alpha$-glucosidase [58]. A set of nine 1,3-dihydroxylated (benzo)xanthones bearing nitro, amino and other alkylating substituents 221-229 were prepared from the corresponding 1,3-dihydroxy (benzo) xanthones and tested towards $\alpha$-glucosidase activity (positive control 1-deoxynojirimycin ( $\mathrm{IC}_{50}=26.4 \mu \mathrm{M}$, Table 9) [59]. As previously reported, a higher inhibitory effect was observed for the benzoxanthone derivatives 225-229 $\left(\mathrm{IC}_{50}=5.9-67.3 \mu \mathrm{M}\right)$ when compared with the xanthone derivatives 221-224 ( IC $_{50}$ values of 102.3-235.2 $\mu \mathrm{M})$ [59].

In 2009, Raj et al. reported the inhibitory effects against $\alpha$ glucosidase by a series of alkylated xanthones bearing prenyl substituents 230 and 232, geranyl 231 and 233, farnesyl 234 and solanesyl substituents $\mathbf{2 3 5}$, and the results are depicted in Table 10 [84]. The variation in the chain length did not affect the inhibitory profile against $\alpha$-glucosidase, varying from 30.9 to $30.9 \%$ of inhibition, at the maximum tested concentration, $100 \mu \mathrm{M}$. No information was given by the authors about the use of a positive control.

A group of novel xanthone derivatives 236-247, having one or two hydroxylnaphthalene moieties at the $\mathrm{C}-2$ and $\mathrm{C}-4$ positions, at the xanthone core, were synthetized and evaluated for their inhibition of $\alpha$-glucosidase activity (Table 11) [60]. To establish a structure-activity relationship, the authors compared the $\mathrm{IC}_{50}$ values obtained with those of the previously reported parent

Table 10

Inhibitory effect of synthetic xanthones $\mathbf{2 3 0 - 2 3 5}$ on $\alpha$-glucosidase activity ${ }^{\mathrm{a}}{ }^{\mathrm{b}}$ [84].

\begin{tabular}{|c|c|c|c|c|c|}
\hline Comp. & $\mathrm{R}$ & \% Inhibition & Comp. & $\mathrm{R}$ & \% Inhibition \\
\hline 230 & 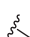 & 31.0 & 232 & s & 42.1 \\
\hline \multirow[t]{3}{*}{231} & & 43.1 & 233 & & 30.9 \\
\hline & & & 234 & s & 66.2 \\
\hline & & & 235 & & 34.5 \\
\hline
\end{tabular}

\footnotetext{
a Positive control: data not shown.

b Percentage of inhibition at the highest tested concentration $(100 \mu \mathrm{M})$.
} 
Table 11

Inhibitory effect of synthetic xanthones 236-247 on baker's yeast $\alpha$-glucosidase activity [60].



compounds [56]. Firstly, and according to the results, the inhibitory effect was augmented with the increasing number of free hydroxyl groups. Second, xanthones 236-239 bearing one $\beta$-naphthol group presented a higher inhibitory effect than the corresponding parent compounds (Table 8) [respectively $25\left(\mathrm{IC}_{50}=160.8 \mu \mathrm{M}\right), \mathbf{1 9 2}$ $\left(\mathrm{IC}_{50}=41.5 \mu \mathrm{M}\right), 26\left(\mathrm{IC}_{50}=17.1 \mu \mathrm{M}\right)$ and $\left.247 \quad\left(\mathrm{IC}_{50}>200 \mu \mathrm{M}\right)\right]$, whereas compounds 240-242 with two $\beta$-naphthol moieties exhibited an even higher inhibition. On the other hand, compounds 243-246 bearing one dihydroxynaphthalenyl group, displayed a lower activity, when compared to their corresponding analogs 236-239, which have one naphthol group. Third, compounds 237-242 and 245 (IC 50 ranging from 6.2 to $26.5 \mu \mathrm{M}$ ) were more active than the positive control 1-deoxynojirimycin $\left(\mathrm{IC}_{50}=40 \mu \mathrm{M}\right)$, while the remaining derivatives showed $\mathrm{IC}_{50}>40 \mu \mathrm{M}$. In addition, the authors have made inhibitory kinetics studies using Lineweaver-Burk plots, to evaluate the type of yeast's $\alpha$-glucosidase inhibition. 1,3,6,8-Tetrahydroxyxanthone 26, xanthone 238 and xanthone $\mathbf{2 4 5}$ were used as typical examples, and the results suggested that the analyzed compounds were noncompetitive inhibitors. Moreover, the inhibitory constants $\left(\mathrm{K}_{\mathrm{i}}\right)$ are reflective of the binding affinity of the inhibitor for the enzyme, constituting a useful tool to compare the activity of the compounds. Thus, the experimental $\mathrm{K}_{\mathrm{i}}$ were $62.8 \mu \mathrm{M}$ for compound 26, $29.2 \mu \mathrm{M}$ for compound 238 and $50.9 \mu \mathrm{M}$ for compound 245, respectively, showing that the compound $\mathbf{2 3 8}$ is the xanthone that better inhibits $\alpha$-glucosidase activity [60].

Li et al. also prepared a series of 3-acyloxyxanthones 248-263 through esterification of 1,3-dihydroxyxanthone $\mathbf{2 5}$ and screened their biological activity toward $\alpha$-glucosidase activity [61]. From the obtained $\mathrm{IC}_{50}$, values listed in Table 12 , all of the tested xanthones exhibited enhanced activity ( $\mathrm{IC}_{50}$ ranging from $10.6 \pm 1.7$ to $105.5 \pm 1.5 \mu \mathrm{M})$ than the precursor xanthone 25 $\left(\mathrm{IC}_{50}=145.0 \pm 15.0 \mu \mathrm{M}\right)$ to inhibit $\alpha$-glucosidase activity. Moreover, compounds $\mathbf{2 4 8}-\mathbf{2 5 0}, \mathbf{2 5 4}, \mathbf{2 5 6}-\mathbf{2 5 8}, \mathbf{2 6 0}-\mathbf{2 6 3}$ were more effective

Table 12

Inhibitory effect of synthetic xanthones $\mathbf{2 4 8}-\mathbf{2 6 3}$ on baker's yeast $\alpha$-glucosidase activity ${ }^{\text {b b }}$ [61].

\begin{tabular}{|c|c|c|c|c|c|}
\hline Comp. & $\mathrm{R}$ & $\mathrm{IC}_{50}(\mu \mathrm{M})$ & Comp. & $\mathrm{R}$ & $\mathrm{IC}_{50}(\mu \mathrm{M})$ \\
\hline 248 & & $36.1 \pm 5.3$ & 256 & 3 & $13.3 \pm 1.4$ \\
\hline 249 & & $30.6 \pm 7.9$ & 257 & & $23.2 \pm 3.9$ \\
\hline 250 & & $21.6 \pm 2.5$ & 258 & & $19.8 \pm 2.6$ \\
\hline 251 & & $46.7 \pm 3.2$ & 259 & & $58.2 \pm 4.9$ \\
\hline 252 & & $42.0 \pm 0.1$ & 260 & & $10.6 \pm 1.7$ \\
\hline 253 & 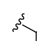 & $42.6 \pm 4.4$ & 261 & & $31.6 \pm 0.8$ \\
\hline 254 & & $23.7 \pm 2.0$ & 262 & & $21.8 \pm 0.6$ \\
\hline 255 & & $105.5 \pm 1.5$ & 263 & & $11.6 \pm 2.2$ \\
\hline
\end{tabular}

${ }^{a}$ Positive control: 1-deoxynojirimycin ( $\left.\mathrm{IC}_{50} 40 \mu \mathrm{M}\right)$.

b In this work, 1,3-dihydroxyxanhtone 25 was also tested and presented an $\mathrm{IC}_{50}=145.0 \pm 15.0 \mu \mathrm{M}$. 
than the positive control, 1-deoxynojirimycin $\left(\mathrm{IC}_{50}=40 \mu \mathrm{M}\right)$. A structure activity relationship analysis suggests that the introduction of an additional aromatic moieties, through the acylation of 3$\mathrm{OH}$ position, may represent an efficient way to improve the inhibitory activity against $\alpha$-glucosidase. Docking studies were performed to evaluate the binding behavior of the compounds and the results pointed out that the interaction of these xanthones with $\alpha$-glucosidase, is favored by $\pi$-stacking or hydrophobic effects of the additional aromatic nucleus rather than the H-bonding donor interaction of 3-OH group. Furthermore, the most active compounds $256\left(\mathrm{IC}_{50}=13.3 \pm 1.4 \mu \mathrm{M}\right), \mathbf{2 6 0}\left(\mathrm{IC}_{50}=10.6 \pm 1.7 \mu \mathrm{M}\right)$ and $263\left(\mathrm{IC}_{50}=11.6 \pm 2.2 \mu \mathrm{M}\right)$ were selected to study the kinetic parameters, determined by Lineweaver-Burk plots. Docking studies, together with the kinetic results, revealed that the 3arylacyloxyxanthone derivatives act as noncompetitive inhibitors of yeast's $\alpha$-glucosidase. The inhibitory constants $K_{i}$ were $17.8 \mu \mathrm{M}$ for compound 256, $13.3 \mu \mathrm{M}$ for compound 260 and $18.0 \mu \mathrm{M}$ for compound 263, showing that compound $\mathbf{2 6 0}$ better binds to the enzyme, inhibiting it more efficiently [61].

In order to predict the $\alpha$-glucosidase inhibitory activity according to the physical and chemical properties of the bioactive compounds, a series of quantitative structure-activity relationship (QSAR) studies have been performed, providing useful information about the interactions between the enzyme and the potential inhibitors. Thus, in 2008, Liu et al. used a multiple linear regression (MLR) method in combination with the Elimination Stepwise as variable selection algorithm, to establish QSAR models for the 41 xanthones previously described (derivatives 25, 26, 50, 188-193, 195-209, 212, 213 and 215-229). Among 38 typical descriptors analyzed, the three descriptors $\mathrm{Hs}$ (number of $\mathrm{H}$-bond forming substituents), $\mathrm{N} \pi$ (number of aromatic rings), and $\mathrm{S}$ (softness value) on the xanthone nucleus, showed a positive correlation with the inhibitory activity. The accuracy and predictivity of the proposed QSAR model were verified by internal validation [cross-validation by leave-one-out (LOO) and Y-randomization] and test group validation with the studied xanthones. From this study, the authors concluded that the introduction of substituents, capable of $\mathrm{H}$-bond formation, such as hydroxyl and amino groups and/or more aromatic groups coupled to the xanthone core, were requirements for rational design of novel and potent $\alpha$-glucosidase inhibitors [59]. One year later, the same xanthones were analyzed through a linear QSAR model developed by a similar MLR method, but applying genetic algorithms to select the appropriate descriptors [85]. The two most important selected descriptors (Van der Waals volumes and electronegativity of atoms and groups) are related to each other, showing that the presence of electron-withdrawing substituents on the aromatic ring result in an unfavorable effect with the electronegativity. In addition, the increase of the aromatic ring number, seems to be a favorable factor to enhance the $\alpha$-glucosidase inhibitory potential. The proposed model presented good stability, robustness and predictivity, given by internal and external validation [85]. The authors compared these results with those obtained from a nonlinear QSAR model, using a back-propagation neural network method, and concluded that Van der Waals volumes were the most important independent variable on the $\alpha$ glucosidase inhibitory effect [86]. Two more studies were reported concerning QSAR models for the xanthones 25, 26, 50, 188-193, 195-209, 212, 213 and 215-229: i) Moorthy et al. which used V life MDS (Molecular Design Suite) and Statistica software and verified that hydrophilic, polar and/or electron negative groups, which are responsible for hydrogen bonding and interaction with the enzyme, are favorable for the inhibitory potential [87] and ii) Masand et al. which used a k-cluster analysis to infer that the presence of 7-OH substituent and the increase of aromatic rings in the xanthone skeleton, increase the $\alpha$-glucosidase inhibitory activity [88].
QSAR studies using linear free energy relationship model of Hansch were conducted on the 25 xanthones already described (25, $\mathbf{2 6}, \mathbf{5 0}, \mathbf{1 8 8}-\mathbf{1 9 3}, \mathbf{1 9 5}-\mathbf{2 0 9}, \mathbf{2 1 2}, \mathbf{2 1 3}$ ). These studies were performed using steric and topological indices parameters along with the appropriate dummy variables. Multi-regression analysis suggested that denser and bulkier groups are beneficial for the inhibitory potential. In addition, acetoxy groups at C-2 and hydroxyl groups at C-4 enhanced while the presence of hydrogen at C-2 lowered the $\alpha$ glucosidase inhibitory effect. Cross-validation analysis using LOO method confirmed the validity of the models [89].

Saqib et al. tested the known 41 xanthones 25, 26, 50, 188-193, 195-209, 212, 213 and 215-229 in three-dimensional quantitative structure-activity relationship (3D-QSAR) studies, in order to provide information about the 3D structural features for $\alpha$-glucosidase inhibitors [90]. These studies include Comparative Molecular Field Analysis (CoMFA) and Comparative Molecular Similarity Indices Analysis (CoMSIA). Models with good predictive abilities were generated with the cross validated $r^{2}$ values for CoMFA and CoMSIA being 0.580 and 0.610 , respectively. The conventional $r^{2}$ values were 0.949 each for both CoMFA and CoMSIA models. Moreover, for docking based alignment of the compounds, a homology model of human $\alpha$-glucosidase was used and the most active compound (216) was the template for the remaining structures, in order to align all compounds, prior to QSAR studies. The results gave an idea about the bioactive conformations that these inhibitors adopt within the $\alpha$-glucosidase active site. Further, mapping of contours onto the active site validated each other in terms of residues involved with reference to respective contours [90]. Recently, Zheng et al. performed a similar docking-assisted 3D-DSAR studies on 54 xanthones (the already reported xanthones $25, \mathbf{2 6}, \mathbf{5 0}$, 188-193, 195-209, 212, 213, 215-229 plus xanthones 236-246, bearing naphthol groups) as $\alpha$-glucosidase inhibitors [91]. Here, CoMFA and CoMSIA approaches were also used to construct 3DQSAR models and the bioactive conformations were analyzed by docking studies and optimized by the homology modeled structure of $\alpha$-glucosidase. Several robust 3D-QSAR models were established and confirmed externally. Increasing the number of aromatic rings and addition of $\mathrm{H}$-bond acceptor substituents located at $\mathrm{C}-3$, play an important role in the enhancing of the inhibitory effectiveness of the tested xanthones. These structural modifications were consistent with the interaction improvements between the ligand and $\alpha$ glucosidase [91]. Molecular docking studies were also applied to evaluate plausible binding modes of mangiferin $\mathbf{2}$ to $\alpha$-glucosidase. The results showed that mangiferin bonds to both allosteric and orthosteric sites by $\pi-\pi$ interactions. In addition, the difference in the fitness value found for the docking at the allosteric site (68.11) with that in the orthosteric site (59.11) is in agreement with a noncompetitive type of inhibition [92].

A docking-based virtual screening of 189 xanthone derivatives was performed by Lakehal et al. to provide insights into their binding mechanism toward NtMGAM. From binding mode analysis, 20 top-scoring xanthones [see structures 176 (Table 6) and 264-282 (Table 13)] revealed that sulfonamide xanthone derivatives showed favorable binding affinity in comparison with miglitol, used as positive control. These binding affinities are due to significant $\mathrm{H}$-bonding interactions of the xanthone substituents with key catalytic residues of NtMGAM [93].

\section{Conclusions}

The current review has provided insights into the potential inhibitory effect of several xanthones, covering more than 280 natural and synthetic derivatives, against one of the main therapeutic target for diabetes, the enzyme $\alpha$-glucosidase. The comparison of results is difficult due to the variability of the experimental 
Table 13

Chemical structure of xanthones 264-282 used in the molecular docking studies toward $\alpha$-glucosidase [93].

\begin{tabular}{|c|c|c|c|c|c|}
\hline & & & & (1) & \\
\hline Comp. & $\mathrm{R}$ & Comp. & $\mathrm{R}$ & Comp. & $\mathrm{R}$ \\
\hline 264 & & 271 & & 277 & \\
\hline 265 & & 272 & & 278 & \\
\hline 266 & & 273 & & 279 & \\
\hline 267 & مئم & 274 & & 280 & \\
\hline 268 & & 275 & & 281 & \\
\hline 269 & & 276 & & $282^{a}$ & \\
\hline 270 & & & & & \\
\hline
\end{tabular}

a This compound is not a sulfonamide xanthone.

conditions found among the different studies, namely in what concerns the nature of the enzyme, concentration of enzyme and substrate, incubation times, etc. Therefore, in this review a detailed description of the enzyme was provided, as well as, a survey on the techniques and the main experimental conditions that can be found in this type of assays. Undoubtedly, the results pointed out for a wide range of active compounds, and a structure activity relationship was performed whenever possible. To provide a deep insight into the correlation between the analyzed structures and their inhibitory profile, a series of QSAR models have been applied and discussed. Based on this statements, xanthones are undeniably a class of heterocyclic compounds with a privileged motif as $\alpha$ glucosidase inhibitors that deserve special attention for future investigations in the pursuit for novel and improved anti-diabetic agents.

\section{Acknowledgments}

This work received financial support from the European Union (FEDER funds POCI/01/0145/FEDER/007265) and National Funds (FCT/MEC, Fundação para a Ciência e Tecnologia and Ministério da Educação e Ciência) under the Partnership Agreement PT2020 UID/ QUI/50006/2013; FCT UID/QUI/00062/2013, and "Programa Operacional Competitividade e Internacionalização” (COMPETE) (POCI01-0145-FEDER-029241), and under the framework of QREN (NORTE-01-0145-FEDER-000024). Thanks are also due to Faculdade de Farmácia da Universidade do Porto and Instituto Politécnico de Bragança.

\section{References}

[1] K.-S. Masters, S. Bräse, Xanthones from fungi, lichens, and bacteria: the natural products and their synthesis, Chem. Rev. 112 (2012) 3717-3776.

[2] H.R. El-Seedi, D.M.H. El-Ghorab, L. Bohlin, A.-K. Borg-Karlson, U. Goransson, R. Verpoorte, Recent insights into the biosynthesis and biological activities of natural xanthones, Curr. Med. Chem. 17 (2010) 854-901.

[3] L.M.M. Vieira, A. Kijjoa, Naturally-occurring xanthones: recent developments, Curr. Med. Chem. 12 (2005) 2413-2446.

[4] T.B.P. Oldenburg, H. Wilkes, B. Horsfield, A.C.T. van Duin, D. Stoddart, A. Wilhelms, Xanthones - novel aromatic oxygen-containing compounds in crude oils, Org. Geochem. 33 (2002) 595-609.

[5] J.S. Negi, V.K. Bisht, P. Singh, M.S.M. Rawat, G.P. Joshi, Naturally occurring xanthones: chemistry and biology, J. Appl. Chem. (2013), 621459, 9 pages.

[6] I. Ahmad Shagufta, Recent insight into the biological activities of synthetic xanthone derivatives, Eur. J. Med. Chem. 116 (2016) 267-280.

[7] S. Jindarat, Xanthones from mangosteen (Garcinia mangostana): multitargeting pharmacological properties, J. Med. Assoc. Thai. 97 (2) (2014) S196-S201.

[8] M.M.M. Pinto, M.E. Sousa, M.S.J. Nascimento, Xanthone derivatives: new insights in biological activities, Curr. Med. Chem. 12 (2005) 2517-2538.

[9] Y. Na, Recent cancer drug development with xanthone structures, J. Pharm. Pharmacol. 61 (2009) 707-712.

[10] M. Riscoe, J.X. Kelly, R. Winter, Xanthones as antimalarial agents: discovery, mode of action, and optimization, Curr. Med. Chem. 12 (21) (2005) 2539-2549.

[11] S.S. Panda, M. Chand, R. Sakuja, S.C. Jain, Xanthones as potential antioxidants, Curr. Med. Chem. 20 (2013) 4481-4507.

[12] A. Chaudhury, C. Duvoor, V.S.R.D.S. Kraleti, A. Chada, R. Ravilla, A. Marco, N.S. Shekhawat, M.T. Montales, K. Kuriakose, A. Sasapu, A. Beebe, N. Patil, C.K. Musham, G.P. Lohani, W. Mirza, Clinical review of antidiabetic drugs: implications for type 2 diabetes mellitus management, Front. Endocrinol. 8 (2017) 12.

[13] H.W. Baynes, Classification, pathophysiology, diagnosis and management of diabetes mellitus, J. Diabetes Metabol. 6 (2015) 541, 9 pages.

[14] M.N. Piero, G.M. Nzaro, J.M. Njagi, Diabetes mellitus - a devastating metabolic disorder, Asian J. Biomed. Pharm. Sci. 40 (2014) 1-7.

[15] American Diabetes Association, Diagnosis and classification of diabetes mellitus, Diabetes Care 37 (2014) S81-S90.

[16] A.A. Siddiqui, S.A. Siddiqui, S. Ahmad, S. Siddiqui, I. Ahsan, K. Sahu, Diabetes: mechanism, pathophysiology and management-a review, Int. J. Drug Dev. Res. 5 (2013) 1-23.

[17] S.E. Kahn, M.E. Cooper, S. Del Prato, Pathophysiology and treatment of type 2 diabetes: perspectives on the past, present, and future, Lancet 383 (2014) 1068-1083.

[18] A.B. Olokoba, O.A. Obateru, L.B. Olokoba, Type 2 diabetes mellitus: a review of current trends, Oman Med. J. 27 (2012) 269-273.

[19] Z. Liu, S. Ma, Recent advances in synthetic $\alpha$-glucosidase inhibitors, ChemMedChem 12 (2017) 819-829.

[20] S. Abid, A. Berraaouan, M. Bnouham, Natural alpha-glucosidase inhibitors: 
therapeutic implication and structure-activity relation ship, Lett. Drug Des. Discov. 7 (2016) 605-637.

[21] S.P. Kasturi, S. Surarapu, S. Uppalanchi, S. Dwivedi, P. Yogeeswari, D.K. Sigalapalli, N.B. Bathini, K.S. Ethiraj, J.S. Anireddy, Synthesis, molecular modeling and evaluation of $\alpha$-glucosidase inhibition activity of 3,4-dihydroxy piperidines, Eur. J. Med. Chem. 150 (2018) 39-52.

[22] S. Kasturi, S. Surarapu, S. Uppalanchi, J.S. Anireddy, S. Dwivedi, H.S. Anantaraju, Y. Perumal, D.K. Sigalapalli, B.N. Babu, K.S. Ethiraj, Synthesis and $\alpha$-glucosidase inhibition activity of dihydroxy pyrrolidines, Bioorg. Med. Chem. Lett. 27 (2017) 2818-2823.

[23] C. Proença, M. Freitas, D. Ribeiro, E.F.T. Oliveira, J.L.C. Sousa, S.M. Tomé, M.J. Ramos, A.M.S. Silva, P.A. Fernandes, E. Fernandes, $\alpha$-Glucosidase inhibition by flavonoids: an in vitro and in silico structure-activity relationship study, J. Enzym. Inhib. Med. Chem. 32 (2017) 1216-1228.

[24] C.M.M. Santos, D.C.G.A. Pinto, V.L.M. Silva, A.M.S. Silva, Arylxanthones and arylacridones: a synthetic overview, Pure Appl. Chem. 88 (2016) 579-594.

[25] C. Proença, H.M.T. Albuquerque, D. Ribeiro, M. Freitas, C.M.M. Santos, A.M.S. Silva, E. Fernandes, Novel chromone and xanthone derivatives: synthesis and ROS/RNS scavenging activities, Eur. J. Med. Chem. 115 (2016) $381-392$.

[26] C.M.M. Santos, A.M.S. Silva, J.A.S. Cavaleiro, Efficient syntheses of new polyhydroxylated 2,3-diaryl-9H-xanthen-9-ones, Eur. J. Org Chem. (2009) 2642-2660.

[27] K. Jones, L. Sim, S. Mohan, J. Kumarasamy, H. Liu, S. Avery, H.Y. Naim, R. Quezada-Calvillo, B.L. Nichols, B.M. Pinto, D.R. Rose, Mapping the intestinal alpha-glucogenic enzyme specificities of starch digesting maltaseglucoamylase and sucrose-isomaltase, Bioorg. Med. Chem. 19 (2011) 3929-3934.

[28] B.L. Nichols, S. Avery, P. Sen, D.M. Swallow, D. Hahn, E. Sterchi, The maltaseglucoamylase gene: common ancestry to sucrase-isomaltase with complementary starch digestion activities, Proc. Natl. Acad. Sci. Unit. States Am. 100 (2003) 1432-1437.

[29] A.H.-M. Lin, B.R. Hamaker, B.L. Nichols Jr., Direct starch digestion by sucraseisomaltase and maltase-glucoamylase, J. Pediatr. Gastroenterol. Nutr. 55 (2012) S43-S45.

[30] M. Diaz-Sotomayor, R. Quezada-Calvillo, S.E. Avery, S.K. Chacko, L.-k. Yan, A.H.-M. Lin, Z.-h. Ao, B.R. Hamaker, B.L. Nichols, Maltase-glucoamylase modulates gluconeogenesis and sucrase-isomaltase dominates starch digestion glucogenesis, J. Pediatr. Gastroenterol. Nutr. 57 (2013) 704-712.

[31] E.H. van Beers, H.A. Büller, R.J. Grand, A.W.C. Einerhand, J. Dekker, Intestinal brush border glycohydrolases: structure, function and development, Crit. Rev. Biochem. Mol. Biol. 30 (1995) 197-262.

[32] R. Quezada-Calvillo, L. Sim, Z. Ao, B.R. Hamaker, A. Quaroni, G.D. Brayer, E.E. Sterchi, C.C. Robayo-Torres, D.R. Rose, B.L. Nichols, Luminal starch substrate "brake" on maltase-glucoamylase activity is located within the glucoamylase subunit, J. Nutr. 138 (2008) 685-692.

[33] B. Gericke, M. Amiri, H.Y. Naim, The multiple roles of sucrase-isomaltase in the intestinal physiology, Mol. Cell. Pediatr. 3 (2) (2016), 6 pages.

[34] O. Wiltz, C.J. O'Hara, G.D. Steele Jr., A.M. Mercurio, Expression of enzymatically active sucrase-isomaltase is a ubiquitous property of colon adenocarcinomas, Gastroenterol. 100 (1991) 1266-1278.

[35] H. Hauser, G. Semenza, Sucrase-isomaltase: a stalked intrinsic protein of the brush border membrane, CRC Crit. Rev. Biochem. 14 (1983) 319-345.

[36] A.H.-M. Lin, Z. Ao, R. Quezada-Calvillo, B.L. Nichols, C.-T. Lin, B.R. Hamaker, Branch pattern of starch internal structure influences the glucogenesis by mucosal Nt-maltase-glucoamylase, Carbohydr. Polym. 111 (2014) 33-40.

[37] L. Ren, X. Qin, X. Cao, L. Wang, F. Bai, G. Bai, Y. Shen, Structural insight into substrate specificity of human intestinal maltase-glucoamylase, Protein Cell 2 (2011) 827-836

[38] F.A. Van de Laar, P.L.B.J. Lucassen, R.P. Akkermans, E.H. Van de Lisdonk, G.E.H.M. Rutten, C. Van Weel, Alpha-glucosidase inhibitors for type 2 diabetes mellitus (review), in: The Cochrane Database of Systematic Reviews, 2005. Issue 2. Art. No.: CD003639.pub2.

[39] Y. Li, T.H.-W. Huang, J. Yamahara, Salacia root, a unique Ayurvedic medicine, meets multiple targets in diabetes and obesity, Life Sci. 82 (2008) 1045-1049.

[40] S.F. Kouam, S.N. Khan, K. Krohn, B.T. Ngadjui, D.G.W.F. Kapche, D.B. Yapna, S. Zareem, A.M.Y. Moustafa, M.I. Choudhary, $\alpha$-Glucosidase inhibitory anthranols, kenganthranols A-C, from the stem bark of Harungana Madagascariensis, J. Nat. Prod. 69 (2006) 229-233.

[41] Z.P. Li, Y.H. Song, Z. Uddin, Y. Wang, K.H. Park, Inhibition of protein tyrosine phosphatase 1B (PTP1B) and a-glucosidase by xanthones from Cratoxylum cochinchinense, and their kinetic characterization, Bioorg. Med. Chem. 26 (2018) 737-746.

[42] N.K. Nguyen, X.A. Truong, T.Q. Bui, D.N. Bui, H.X. Nguyen, P.T. Tran, L.H.D. Nguyen, $\alpha$-Glucosidase inhibitory xanthones from the roots of Garcinia fusca, Chem. Biodivers. 14 (2017), e1700232.

[43] E.J. Seo, M.J. Curtis-Long, B.W. Lee, H.Y. Kim, Y.B. Ryu, T.-S. Jeong, W.S. Leec, K.H. Park, Xanthones from Cudrania tricuspidata displaying potent $\alpha$-glucosidase inhibition, Bioorg. Med. Chem. Lett 17 (2007) 6421-6424.

[44] H.W. Ryu, J.K. Cho, M.J. Curtis-Long, H.J. Yuk, Y.S. Kim, S. Jung, Y.S. Kim, B.W. Lee, K.H. Park, $\alpha$-Glucosidase inhibition and antihyperglycemic activity of prenylated xanthones from Garcinia mangostana, Phytochemistry 72 (2011) 2148-2154.

[45] C.C. Jia, T. Han, J. Xu, S.G. Li, Y.T. Sun, D.H. Li, Z.L. Li, H.M. Hua, A new biflavonoid and a new triterpene from the leaves of Garcinia paucinervis and their biological activities, J. Nat. Med. 71 (2017) 642-649.

[46] T. Chen, H. Li, C. Chen, L. Wei, Y. Li, Large-scale preparation of a specific xanthone from Swertia mussotii and evaluation of its $\alpha$-glucosidase inhibitory activity, J. Chromatogr. Sci. (2017) 1-7.

[47] I. Polbuppha, W. Maneerat, T. Sripisut, T. Limtharakul, S. Cheenpracha, S.G. Pyne, C. Muanprasat, S. Seemakha, S. Borwornpinyo, S. Laphookhieo, Antioxidant, cytotoxic and $\alpha$-glucosidase inhibitory activities of compounds isolated from the twig extracts of Maclura fruticosa, Nat. Prod. Commun. 12 (2017) 1073-1076.

[48] L.-S. Wan, Q.-X. Min, Y.-L. Wang, Y.-D. Yue, J.-C. Chen, Xanthone glycoside constituents of Swertia kouitchensis with $\alpha$-glucosidase inhibitory activity, J. Nat. Prod. 76 (2013) 1248-1253.

[49] Y. Chen, S. He, C. Tang, J. Li, G. Yang, Caged polyprenylated xanthones from the resin of Garcinia hanburyi, Fitoterapia 109 (2016) 106-112.

[50] J. Zuo, C.-L. Ji, Y. Xia, X. Li, J.-W. Chen, Xanthones as $\alpha$-glucosidase inhibitors from the antihyperglycemic extract of Securidaca inappendiculata, Pharm. Biol 52 (2014) 898-903.

[51] J.-F. Wang, L.-M. Zhou, S.-T. Chen, B. Yang, S.-R. Liao, F.-D. Kong, X.-P. Lin, F.Z. Wang, X.-F. Zhou, Y.-H. Liu, New chlorinated diphenyl ethers and xanthones from a deep-sea-derived fungus Penicillium chrysogenum SCSIO 41001, Fitoterapia 125 (2018) 49-54.

[52] Y.-D. Yue, Y.-T. Zhang, Z.-X. Liu, Q.-X. Min, L.-S. Wan, Y.-L. Wang, Z.-Q. Xiao, J.C. Chen, Xanthone glycosides from Swertia bimaculata with $\alpha$-glucosidase inhibitory activity, Planta Med. 80 (2014) 502-508.

[53] T.-T. Ma, W.-G. Shan, Y.-M. Ying, L.-F. Ma, W.-H. Liu, Z.-J. Zhan, Xanthones with $\alpha$-glucosidase inhibitory activities from Aspergillus versicolor, a fungal endophyte of Huperzia serrata, Helv. Chim. Acta 98 (2015) 148-152.

[54] H. Fouotsa, A.M. Lannang, C.D. Mbazoa, S. Rasheed, B.P. Marasini, Z. Ali, K.P. Devkota, A.E. Kengfack, F. Shaheen, M.I. Choudhary, N. Sewald, Xanthones inhibitors of $\alpha$-glucosidase and glycation from Garcinia nobilis, Phytochemistr. Lett. 5 (2012) 236-239.

[55] T. Sriyatep, I. Siridechakorn, W. Maneerat, A. Pansanit, T. Ritthiwigrom, R.J. Andersen, S. Laphookhieo, Bioactive prenylated xanthones from the young fruits and flowers of Garcinia cowa, J. Nat. Prod. 78 (2015) 265-271.

[56] Y. Liu, L. Zou, L. Ma, W.-H. Chen, B. Wang, Z.-L. Xu, Synthesis and pharmacological activities of xanthone derivatives as $\alpha$-glucosidase inhibitors, Bioorg. Med. Chem. 14 (2006) 5683-5690.

[57] Y. Liu, L. Ma, W.-H. Chen, B. Wang, Z.-L. Xu, Synthesis of xanthone derivatives with extended p-systems as $\alpha$-glucosidase inhibitors: insight into the probable binding mode, Bioorg. Med. Chem. 15 (2007) 2810-2814.

[58] Y. Liu, L. Ma, W.-H. Chen, H. Park, Z. Ke, B. Wang, Binding mechanism and synergetic effects of xanthone derivatives as noncompetitive $\alpha$-glucosidase inhibitors: a theoretical and experimental study, J. Phys. Chem. B 117 (2013) $13464-13471$.

[59] Y. Liu, Z. Ke, J. Cui, W.-H. Chen, L. Ma, B. Wang, Synthesis, inhibitory activities, and QSAR study of xanthone derivatives as $\alpha$-glucosidase inhibitors, Bioorg. Med. Chem. 16 (2008) 7185-7192.

[60] G.-L. Li, J.-Y. He, A. Zhang, Y. Wan, B. Wang, W.-H. Chen, Toward potent $\alpha$ glucosidase inhibitors based on xanthones: a closer look into the structureactivity correlations, Eur. J. Med. Chem. 46 (2011) 4050-4055.

[61] G.-L. Li, C.-Y. Cai, J.-Y. He, L. Rao, L. Ma, Y. Liu, B. Wang, Synthesis of 3acyloxyxanthone derivatives as $\alpha$-glucosidase inhibitors: a further insight into the 3-substituents' effect, Bioorg. Med. Chem. 24 (2016) 1431-1438.

[62] C.N. Nguyen, B.T.D. Trinh, T.B. Tran, L.-T.T. Nguyen, A.K. Jäger, L.-H.D. Nguyen, Anti-diabetic xanthones from the bark of Garcinia xanthochymus, Bioorg. Med Chem. Lett 27 (2017) 3301-3304.

[63] B.T.D. Trinh, T.T.T. Quach, D.N. Bui, D. Staerk, L.-H.D. Nguyen, A.K. Jäger Xanthones from the twigs of Garcinia oblongifolia and their antidiabetic activity, Fitoterapia 118 (2017) 126-131.

[64] S. Phoboo, M.S. Pinto, A.C.L. Barbosa, D. Sarkar, P.C. Bhowmik, P.K. Jha, K. Shetty, Phenolic-linked biochemical rationale for the anti-diabetic properties of Swertia chirayita (Roxb. ex Flem.) Karst, Phytother Res. 27 (2013) 227-235.

[65] H. Ichiki, O. Takeda, I. Sakakibara, S. Terabayashi, S. Takeda, H. Sasaki, Inhibitory effects of compounds from Anemarrhenae Rhizoma on $\alpha$-glucosidase and aldose reductase and its contents by drying conditions, J. Nat. Med. 61 (2007) 146-153.

[66] Y. Li, G. Peng, Q. Li, S. Wen, T.H.-W. Huang, B.D. Roufogalis, J. Yamahara, Salacia oblonga improves cardiac fibrosis and inhibits postprandial hyperglycemia in obese zucker rats, Life Sci. 75 (2004) 1735-1746.

[67] S.C. Bosman, D. de Beer, T. Beelders, E.L. Willenburg, C.J. Malherbe, B. Walczak, E. Joubert, Simultaneous optimisation of extraction of xanthone and benzophenone $\alpha$-glucosidase inhibitors from Cyclopia genistoides and identification of superior genotypes for propagation, J. Funct. Foods 33 (2017) 21-31.

[68] H.W. Ryu, S.H. Jeong, M.J. Curtis-Long, S. Jung, J.W. Lee, H.S. Woo, J.K. Cho, K.H. Park, Inhibition effects of mangosenone $\mathrm{F}$ from Garcinia mangostana on melanin formation in B16F10 cells, J. Agric. Food Chem. 60 (2012) 8372-8378.

[69] J. Feng, X.-W. Yang, R.-F. Wang, Bio-assay guided isolation and identification of $\alpha$-glucosidase inhibitors from the leaves of Aquilaria sinensis, Phytochemistry 72 (2011) 242-247.

[70] M. Mosihuzzman, S. Naheed, S. Hareem, S. Talib, G. Abbas, S.N. Khan, M.I. Choudhary, B. Sener, R.B. Tareen, M. Israr, Studies on $\alpha$-glucosidase inhibition and anti-glycation potential of Iris loczyi and Iris unguicularis, Life Sci. 92 (2013) 187-192.

[71] C.-T. Luo, H.-H. Zheng, S.-S. Mao, M.-X. Yang, C. Luo, H. Chen, Xanthones from 
Swertia mussotii and their $\alpha$-glycosidase inhibitory activities, Planta Med. 80 (2014) 201-208.

[72] H.-H. Zheng, C.-T. Luo, H. Chen, J.-N. Lin, C.-L. Ye, S.-S. Mao, Y.-L. Li, Xanthones from Swertia mussotii as multitarget-directed antidiabetic agents, ChemMedChem 9 (2014) 1374-1379.

[73] S.-H. Nian, H.-J. Li, E.-H. Liu, P. Li, Comparison of $\alpha$-glucosidase inhibitory effect and bioactive constituents of Anemarrhenae rhizoma and fibrous roots, J. Pharmaceut. Biomed. Anal. 145 (2017) 195-202.

[74] C. Uvarani, K. Arumugasamy, K. Chandraprakash, M. Sankaran, A. Ata, P.S. Mohan, A new DNA-intercalative cytotoxic allylic xanthone from Swertia corymbosa, Chem. Biodivers. 12 (2015) 358-370.

[75] S. Saha, P. Sadhukhan, P.C. Sil, Mangiferin: a xanthonoid with multipotent anti-inflammatory potential, Biofactors 42 (2016) 459-474.

[76] Jotshna, P. Khare, K. Shanker, Mangiferin: a review of sources and interventions for biological activities, Biofactors 42 (2016) 504-514.

[77] A. Matkowski, P. Kus, E. Góralska, D. Wozniak, Mangiferin - a bioactive xanthonoid, not only from mango and not just antioxidant, Mini rev. Med. Chem. 13 (2013) 439-455.

[78] M. Yoshikawa, N. Nishida, H. Shimoda, M. Takada, Y. Kawahara, H. Matsuda, Polyphenol constituents from Salacia species: quantitative analysis of mangiferin with $\alpha$-glucosidase and aldose reductase inhibitory activites, Yakugaku Zasshi 121 (2001) 371-378.

[79] A.N.B. Singab, I.M. Ayoub, M. El-Shazly, M. Korinek, T.-Y. Wu, Y.-B. Cheng, F.R. Chang, Y.-C. Wu, Shedding the light on Iridaceae: ethnobotany, phytochemistry and biological activity, Ind. Crop. Prod. 92 (2016) 308-335.

[80] K. Sanugul, T. Akao, Y. Li, N. Kakiuchi, N. Nakamura, M. Hattori, Isolation of a human intestinal bacterium that transforms mangiferin to norathyriol and inducibility of the enzyme that cleaves a C-glucosyl bond, Biol. Pharm. Bull. 28 (2005) 1672-1678.

[81] L. Gao, Y. Zhou, H. Yan, F. Huang, R. Wen, G. Li, Two new xanthone glucosides from Swertia mussotii Franch, Heterocycles 83 (2011) 1897-1902.

[82] J. Li, Y.-L. Zhao, H.-Y. Huang, Y.-Z. Wang, Phytochemistry and pharmacological activities of the genus Swertia (Gentianaceae): a review, Am. J. Chin. Med. 45 (2017) 1-70
[83] H.T. Shandiz, B.M. Razavi, H. Hosseinzadeh, Review of Garcinia mangostana and its xanthones in metabolic syndrome and related complications, Phytother Res. 31 (2017) 1173-1182.

[84] K. Raj, N. Misra, G. Pachauri, M. Sharma, A.K. Tamrakar, A.B. Singh, A.K. Srivastava, K.P. Kiran, C.V.N. Rao, S.R. Prubhu, Novel class of hybrid natural products as antidiabetic agentes, Nat. Prod. Res. 23 (2009) 60-69.

[85] K. Kraim, D. Khatmi, Y. Saihi, F. Ferkous, M. Brahimi, Quantitative structure activity relationship for the computational prediction of $\alpha$-glucosidase inhibitory, Chemometr. Intell. Lab. 97 (2009) 118-126.

[86] Y. Saihi, K. Kraim, F. Ferkous, Z. Djeghaba, A. Azzouzi, S. Benouis, Nonlinear QSAR study of xanthone and curcuminoid derivatives as $\alpha$-glucosidase inhibitors, Bull. Kor. Chem. Soc. 34 (2013) 1643-1650.

[87] N.S.H.N. Moorthy, M.J. Ramos, P.A. Fernandes, Topological, hydrophobicity, and other descriptors on $\alpha$-glucosidase inhibition: a QSAR study on xanthone derivatives, J. Enzym. Inhib. Med. Chem. 26 (2011) 755-766.

[88] V.H. Masand, D.T. Mahajan, K.N. Patil, K.D. Chinchkhede, R.D. Jawarkar, T.B. Hadda, A.A. Alafeefy, I.G. Shibi, k-NN, Quantum mechanical and field similarity based analysis of xanthone derivatives as $\alpha$-glucosidase inhibitors, Med. Chem. Res. 21 (2012) 4523-4534.

[89] A.K. Srivastava, A. Pandey, A. Nath, M. Jaiswal, V.K. Pathak, Quantitative structure activity relationship studies on a series of xanthone derivatives as $\alpha$ glucosidase inhibitors, Oxid. Commun. 33 (2010) 195-204.

[90] U. Saqib, M.I. Siddiqi, 3D-QSAR studies of xanthone derivatives as human alpha glucosidase inhibitors, Int. J. Integr. Biol. 5 (2009) 13-19.

[91] X. Zheng, S. Zhou, C. Zhang, D. Wu, H.-B. Luo, Y. Wu, Docking-assisted 3DQSAR studies on xanthones as $\alpha$-glucosidase inhibitors, J. Mol. Model. 23 (2017), 272 (12 pages).

[92] M.C.N. Picot, G. Zengin, A. Mollica, A. Stefanucci, S. Carradori, M.F. Mahomoodally, In vitro and in silico studies of mangiferin from Apholia theiformis on key enzymes linked to diabetes type 2 and associated complications, Med. Chem. 13 (2017) 633-640.

[93] S. Lakehala, F. Ferkousa, K. Kraima, O.A. Yahiaa, Y. Saihi, Mmolecular docking study on xanthone derivatives toward alpha-glucosidase, Res. J. Pharmaceut. Biol. Chem. Sci. 7 (2016) 1739-1750. 